Universidad de Lima

Escuela de Posgrado

Maestría en Derecho Empresarial

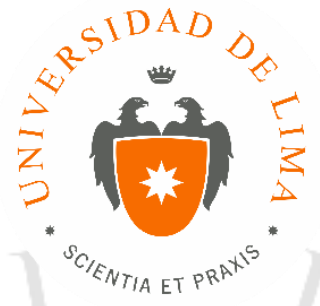

\title{
RESPONSABILIDAD DEL ARRENDADOR FINANCIERO POR ACCIDENTES VEHICULARES: APORTES PARA UNA ADECUADA REGULACIÓN EN EL PERÚ
}

Trabajo de investigación para optar el Grado Académico de Maestro en

Derecho Empresarial

Johanna Landeras Cantuarias

Código: 19982376

Asesor: Antonio Román Calzada

Lima - Perú 


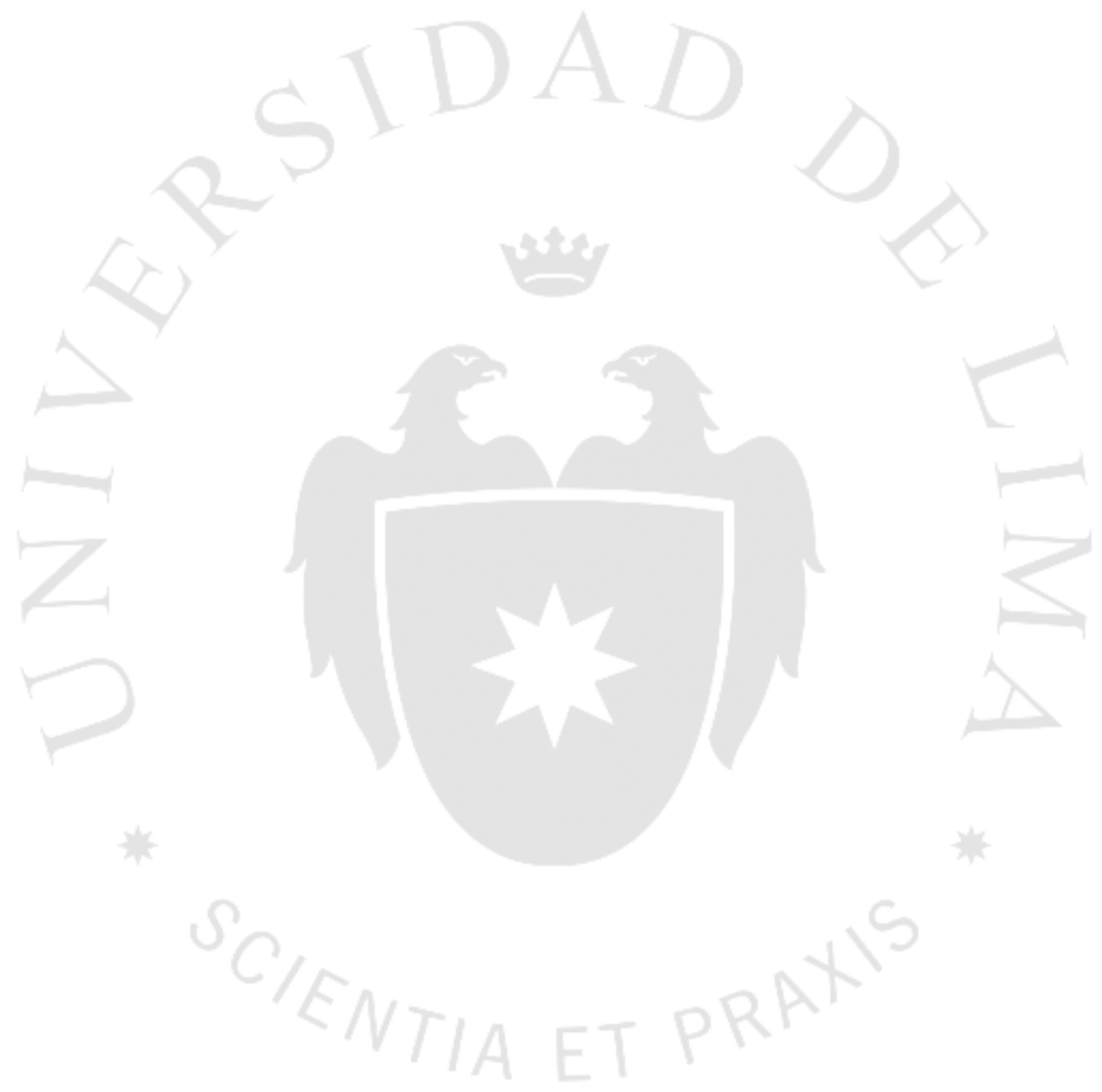




\section{RESPONSABILIDAD DEL ARRENDADOR FINANCIERO POR ACCIDENTES \\ VEHICULARES: APORTES PARA UNA ADECUADA REGULACIÓN EN EL PERÚ}




\section{TABLA DE CONTENIDOS}

INTRODUCCIÓN 1

\section{CAPITULO I: RESPONSABILIDAD DEL PROPIETARIO POR ACCIDENTES VEHICULARES

1.1 Análisis de la responsabilidad por riesgo: .6

1.2 Responsabilidad del propietario del vehículo automotor según la Ley General de Transporte y Tránsito terrestre y su Reglamento:. .10

1.3 Análisis de la responsabilidad civil del propietario que actúa como arrendador financiero:

1.4 Conclusiones del capítulo: .16

CAPITULO II: ASPECTOS GENERALES DEL CONTRATO DE

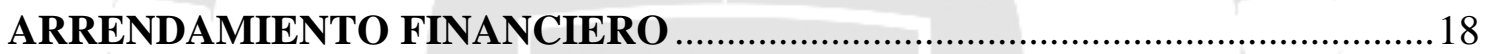

2.1 Definición del Leasing o Arrendamiento Financiero:.....................18

2.2 Naturaleza Jurídica del Leasing:..................................20

2.2.1 Teoría del Arrendamiento:...........................................20

2.2.2 Teoría de la Compraventa:.........................................22

2.2.3 Teoría del Préstamo:...........................................23

2.2.4 Nuestra posición:..............................................25

2.3 Características del Contrato de Arrendamiento Financiero:.................25

2.4 Elementos del Contrato de Leasing:..................................29

2.4.1 Elementos Subjetivos:.......................................29

2.4.2 Elementos Objetivos:............................................30

2.5 Modalidades de Leasing:............................................. 32

2.6 Ventajas del Leasing como fuente de financiamiento: ............................... 33

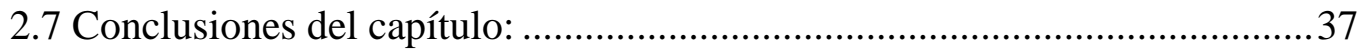


CAPITUlO III: PROBLEMÁtiCA JUDICIAL Y PROPUESTA DE

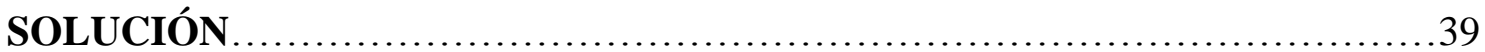

3.1 Análisis de jurisprudencia peruana sobre responsabilidad civil del arrendador

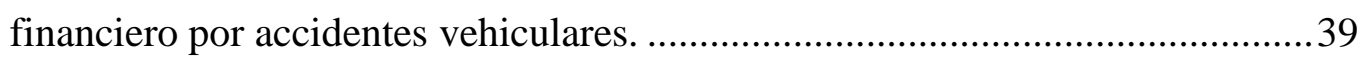

3.2 Legislación comparada:...............................................50

3.3 Propuesta de solución del marco jurídico:...................................55

3.4 Conclusiones del capítulo:............................................64

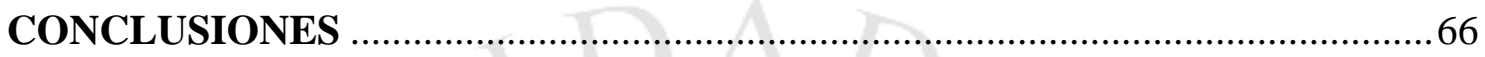

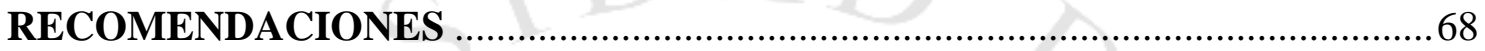

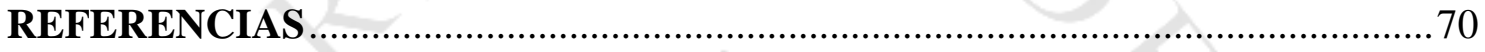




\section{INTRODUCCIÓN}

El Leasing o arrendamiento financiero es una operación financiera, regulada en nuestro país por el Decreto Legislativo $N^{\circ} 299$ y por su Reglamento aprobado por el D.S N ${ }^{\circ} 559$ 84-EFC. Nuestro Código Civil, en su artículo $1677^{\circ}$ señala que el contrato de arrendamiento financiero se rige por su legislación especial y, supletoriamente, por las normas del contrato de arrendamiento, y los artículos 1419 a 1425 (artículos que se refieren a los contratos preparatorios), en cuanto sean aplicables.

Si bien el Leasing contiene una serie de características que lo diferencian de otras figuras jurídicas, el artículo 1 del Decreto Legislativo $N^{\circ} 299$ lo define como aquel:

Contrato mercantil que tiene por objeto la locación de bienes muebles o inmuebles por una empresa locadora para el uso por la arrendataria, mediante el pago de cuotas periódicas y con opción a favor de la arrendataria de comprar dichos bienes por un valor pactado.

Como se puede apreciar, el Leasing constituye una herramienta fundamental para todo tipo de empresas, pues otorga la posibilidad de adquirir bienes de capital cuando estas no cuentan con el efectivo necesario para hacerlo o que disponiendo de tales recursos buscan destinarlos a otra finalidad susceptible de mejorar su rentabilidad. De la misma manera, el referido contrato reduce los costos del crédito al mantener la titularidad de los bienes a favor del Banco o empresa de Leasing; ello aunado a los importantes beneficios tributarios que conlleva optar por dicha fuente de financiamiento.

Es importante señalar que, de la revisión de los diversos reportes de la Asociación de Bancos del Perú (en adelante ASBANC), a junio de 2011, los montos de los contratos de arrendamiento financiero otorgados por entidades privadas del Sistema Financiero ascendían a US\$ 7,061 millones. A enero de 2014, el monto financiado con leasing por el sistema financiero alcanzó US\$ 8,234 millones de dólares americanos, lo que demuestra que el leasing a lo largo de los años ha experimentado un crecimiento exponencial, siendo el resultado de ello la creciente demanda de las empresas y el incremento de la oferta por parte de los bancos, financieras y entidades especializadas en arrendamiento financiero. 
Resulta claro entonces que, un gran sector de la economía confía en esta fuente de financiamiento para adquirir bienes de capital, aumentando su capacidad instalada y permitiendo de esta manera la expansión de sus operaciones.

Por otro lado, de las estadísticas obtenidas por ASBANC se puede apreciar que, a octubre de 2016, los activos fijos que requieren las empresas son, en primer lugar, las unidades de transporte terrestre con un $64.25 \%$, en segundo lugar, la maquinaria y equipo industrial con un $20.90 \%$, con un porcentaje mucho menor tenemos a los bienes inmuebles con un 5.15\%; le sigue las maquinarias y equipos de oficina con un $4.45 \%$; maquinaria y equipos de movimiento de tierra con un $1.52 \%$; entre otros.

Estas estadísticas demuestran que, los vehículos son los bienes a los cuales acceden más las empresas a través del leasing. Por tanto, resulta de suma importancia, contar con normas claras que permitan a las partes conocer de antemano las reglas de juego al decidir por una fuente de financiamiento como el leasing y de la misma manera garantizarles que no se verán perjudicadas al incrementarse los costos de transacción, a lo largo de la vigencia del contrato.

Sin embargo, a pesar de la regulación y características propias que tiene el contrato de Leasing, así como los beneficios que puede contener como fuente de financiamiento, nuestros jueces y tribunales atribuyen responsabilidad al Banco o empresa de Leasing por el sólo hecho de ser "formalmente propietaria del bien", aplicándose la Ley General de Transporte y Tránsito Terrestre, que establece la responsabilidad objetiva y solidaria del propietario del bien en desmedro de lo establecido en la propia Ley de Leasing y su Reglamento.

Cabe resaltar que, el artículo 6 del Decreto Legislativo 299, precisa que:

Los bienes materia de arrendamiento financiero deberán ser cubiertos mediante pólizas contra riesgos susceptibles de afectarlos o destruirlos. Es derecho irrenunciable de la locadora fijar las condiciones mínimas de dicho seguro.

La arrendataria es responsable del daño que pueda causar el bien, desde el momento que lo recibe de la locadora. (Negritas y subrayado es nuestro)

Por su parte, el Artículo 23 del Reglamento, señala que: "Para el efecto a que se refiere el segundo párrafo del artículo 6 de la Ley de arrendamiento financiero, corresponde a la arrendataria asegurar obligatoriamente a los bienes materia de arrendamiento financiero contra riesgos de responsabilidad civil frente a terceros". 
En virtud de lo expuesto, podemos señalar que existen dos normas opuestas. Por un lado tenemos la Ley General de Transporte y Tránsito Terrestre, que establece responsabilidad objetiva del propietario del bien; y por otro lado tenemos la norma especial que regula el leasing como mecanismo de financiamiento, y establece que la responsabilidad recae en el arrendatario del bien.

En ese sentido, y en base a la problemática planteada, consideramos que el tema que se desarrollará a lo largo del presente trabajo de investigación es relevante jurídica y económicamente. Si bien ha sido materia de análisis tanto en la tesis titulada “Arrendamiento Financiero y Responsabilidad Extracontractual de los Bancos" de Elizabeth Chaparro Quispe ${ }^{1}$, así como en la tesis, "La Regulación de la Responsabilidad Solidaria del Arrendador Financiero en el contrato de Leasing" de Alida Jessica Araujo Moreno $^{2}$, nuestro enfoque va dirigido a determinar el fundamento por el cual se le imputa responsabilidad civil al propietario del bien, y ello a fin de deslindar todo tipo de responsabilidad del arrendador financiero. No nos centramos únicamente en estudiar la naturaleza jurídica del arrendamiento financiero, sino más bien vamos más allá, buscando el porqué, en base a las diversa doctrina existente, se le atribuye responsabilidad al propietario del bien sin haber participado del hecho que causó el daño.

Cabe precisar que, si bien la tesis de Chaparro (2017) comparte nuestra posición de no imputar responsabilidad al arrendador financiero, señala principalmente que: (i) $\mathrm{Si}$ se continúa estableciendo responsabilidad a los bancos, el costo de un posible daño será trasladado a los arrendatarios, en forma de incremento de las tasa de interés; (ii) el tratar de privilegiar a los terceros dañados afecta el espíritu de las leyes y más aún se afecta la posibilidad del desarrollo de una herramienta financiera importante y con muchos beneficios para el mercado y; (iii) es importante privilegiar la autonomía privada (contrato de leasing) y la norma especial excluyendo al banco de todo tipo de pretensión resarcitoria (pp. 28, 33 y 43). Por su parte, la tesis de Araujo (2017), asume una posición totalmente contraria a la nuestra, es decir sostiene que: (i) El arrendador financiero es

\footnotetext{
${ }^{1}$ Chaparro, E. (2017). Arrendamiento Financiero y la Responsabilidad Extracontractual de los Bancos (Tesis para optar el grado de Magister en Derecho Bancario y Financiero). Pontificia Universidad Católica del Perú, Lima-Perú.

2 Araujo, A. (2017). La Regulación de la Responsabilidad Solidaria del Arrendador Financiero en el contrato de Leasing (Tesis para optar el título profesional de abogado). Universidad Privada Antenor Orrego, Lima, Perú.
} 
quien debe asumir la responsabilidad civil frente a terceros, debiendo aplicar las normas del Código Civil como en cualquier caso de arrendamiento en general; (ii) Las normas del Decreto Legislativo 299 están destinadas a regular las relaciones que se dan entre las partes que lo celebran y no a regular supuestos de responsabilidad extracontractual, asimismo tampoco limita o determina quién resulta responsable o quien debe resarcir un evento dañoso frente a terceros ajenos al acto jurídico; y (iii) Existe responsabilidad civil por parte del arrendador financiero tomando en cuenta el artículo $4^{\circ}$ del Decreto Legislativo 299, el cual hace mención que la locadora o arrendador, mantendrá la propiedad de dichos bienes dados en leasing (pp. 80-81).

Como se aprecia, y considerando las posiciones contrapuestas que existen en las diversas tesis planteadas sobre el tema en cuestión, hemos considerado importante analizar en el presente trabajo de investigación, la responsabilidad objetiva, propiamente dicha y las diversas teorías que se construyen alrededor de ella, profundizando en el por qué se le imputa responsabilidad civil al propietario del bien, para luego centrarnos en la naturaleza jurídica y características propias del arrendamiento financiero.

De la misma manera, profundizamos en la jurisprudencia a favor y en contra de la responsabilidad del arrendador financiero en caso de accidentes vehiculares, para luego analizar jurisprudencia y normativa extranjera que nos permita proponer mejoras legislativas a fin de que no quepa duda sobre el rol que desempeña el arrendador financiero en todo contrato de leasing. Contar con normas claras permitirá dinamizar el arrendamiento financiero como mecanismo de crédito, evitando pronunciamientos como los que existen actualmente a nivel judicial, que no hacen más que generar inseguridad jurídica para los actores del contrato que es materia de investigación.

En efecto, atribuir responsabilidad al arrendador financiero, a pesar de la legislación vigente, no hace más que perjudicar al arrendatario al trasladársele los costos que ello puede generar, lo cual no siempre se traduce en un incremento de las tasas de interés, sino más bien, por intermedio del contrato, se traslada al arrendatario todos aquellos gastos que el mismo proceso judicial puede generar para el arrendador financiero.

Por tanto, a lo largo del presente trabajo de investigación buscaremos determinar si, efectivamente la legislación actual, que regula el contrato de leasing en nuestro país, 
es lo suficientemente clara a fin de deslindar responsabilidad al arrendador financiero, y, de ser el caso, hacer una propuesta para su mejor regulación. 


\section{CAPITULO I: RESPONSABILIDAD DEL PROPIETARIO POR ACCIDENTES VEHICULARES}

\subsection{Análisis de la responsabilidad por riesgo:}

Nuestro Código Civil regula por separado la responsabilidad civil contractual y la responsabilidad civil extracontractual; en el primer caso, el daño es consecuencia del incumplimiento de una obligación previamente pactada, mientras que, en el segundo caso, el daño es producto del incumplimiento del deber jurídico de no causar daño a los demás.

Ahora bien, en el caso de la responsabilidad civil extracontractual, el sistema adoptado por el Código Civil de 1984 es pues el de la responsabilidad subjetiva y el de la responsabilidad por riesgo como complemento necesario.

En efecto, el Código Civil de 1984 adoptó como principio general la responsabilidad civil subjetiva (por dolo o culpa) armonizándolo con la responsabilidad objetiva (por riesgo o peligro, o por el hecho de los dependientes, auxiliares, o por los daños causados por las cosas). En el caso de la responsabilidad subjetiva, el sujeto está obligado a indemnizar los daños causados por sus actos dolosos, llevados a cabo por intención consiente y deliberada de causar un daño, o culposos producidos por negligencia, descuido, imprudencia o impericia. La responsabilidad objetiva por su parte, implica que no se pueda imputar al responsable ninguna violación a la Ley o negligencia, imprudencia o impericia; siendo uno de los factores objetivos de responsabilidad el riesgo o peligro creado por el uso de un bien o por el ejercicio de una actividad lícita.

El presente trabajo materia de investigación, se centra específicamente en determinar la responsabilidad del arrendador financiero ante accidentes vehiculares, por lo que es de suma importancia analizar lo dispuesto en el artículo 1970 del Código Civil que a la letra dice:

Artículo 1970. Responsabilidad por riesgo: Aquel que mediante un bien riesgoso o peligroso o por el ejercicio de una actividad riesgosa o peligrosa, causa un daño a otro, está obligado a repararlo. 
Tal como señala Espinoza (2016), fuente inspiradora del mismo ha sido el art. 2050 del c.c italiano, el cual establece:

"Quien ocasiona daño a otro en el desarrollo de una actividad peligrosa, por su naturaleza o por la naturaleza de los medios empleados, está obligado al resarcimiento, si no prueba haber adoptado todas las medidas idóneas para evitar el daño" (p.620).

La naturaleza de la responsabilidad establecida en el artículo 1970 es sin lugar a duda objetiva, dado que no se requiere como factor de atribución que el agente actúe con dolo o culpa, sino que por el contrario debe verificarse únicamente (i) la existencia del daño, y (ii) la relación de causalidad adecuada entre el daño y el bien o actividad riesgosa o peligrosa que lo ha ocasionado.

Cabe precisar que, su aplicación se fundamenta en la noción de riesgo creado por un bien o el ejercicio de una actividad que supone un riesgo adicional al ordinario, entendiéndose como aquella circunstancia que agrega un peligro adicional al simple riesgo de vivir en común; y en el caso de peligro, que se genere una mayor proximidad al daño (De Trazegnies F., 2003, pp.159-160).

Es importante desarrollar, para efectos de determinar el fundamento por el cual se le imputa responsabilidad objetiva al propietario de un bien, las construcciones doctrinarias que surgieron en torno a la responsabilidad objetiva. Tenemos, por ejemplo; La teoría del riesgo-beneficio, en la cual, la empresa asume la carga de los daños que "la aplicación de las reglas tradicionales dejaría a las víctimas, por cuanto ésta se ha beneficiado con su actividad. Esta teoría fue sustituida por la denominada teoría del "riesgo-creado", la cual permite aplicar criterios de responsabilidad también en los casos en los cuales, no existiendo actividad empresarial, no se podría aplicar la ecuación "riesgo-beneficio-responsabilidad". En efecto, los accidentes que se producen fuera de las actividades lucrativas, son absorbidas por el principio "el que emplea fuentes de riesgo debe asumir las consecuencias negativas" (Espinoza, 2016, p 188).

Aquí es importante precisar que, la teoría de riesgo creado fue planteada por Louis Josserand a fines del siglo XIX señalando expresamente que:

(...) se es inmediatamente responsable, por razones de equidad y sin que para ello sea necesario analizar el plano subjetivo o el rubro de actividad, de los daños causados por el hecho de las cosas de las que uno se sirve. El deber de resarcir tales daños se concreta en una obligación que nace ex lege, en cabeza de quien genera el riesgo. Este debe ser asumido por aquel que lo ha creado, al margen de todo derecho de propiedad o de otro 
derecho real sobre la cosa (...) El riesgo, noción concreta y de orden especialmente práctico debe ser asumido por el individuo que dispone de la cosa y ejerce el gobierno de esta (...) (Fernández Cruz \& León, 2005, p.92).

Por su parte, Raymond Saleilles (1897) al exponer su teoría acerca de los accidentes laborales, planteó que la víctima, en todos los casos, puede obtener una indemnización por los accidentes laborales. Dicho planteamiento tenía los mismos efectos expuestos por Josserand; esto es borrar toda idea de culpa y de esa manera relevar al trabajador de su prueba, siendo responsable el patrón independientemente de cualquier culpa. Saleilles se basó en el riesgo para sustentar su posición, señalando lo siguiente:

"El que crea una fuente de daño, así el que explota una fábrica, debe reparación si los riesgos se concretan. El exclusivo hecho del perjuicio compromete su responsabilidad; es la contrapartida de los beneficios que obtiene de la empresa. Nace aquí lo que llamamos la teoría del riesgo; teoría que justifica la responsabilidad en el simple hecho de haber generado un riesgo particular (Uribe, 2003. pp. 4-5).

Algunos autores señalan que, el fundamento de la responsabilidad por riesgo puede encontrarse también en ciertos criterios de equidad:

Por regla general se entiende que aquel que se beneficia de una situación debe también soportar las cargas de la misma (ubi commodum ibi et incommodum). Aquella persona que crea dentro de la vida social y en su propio beneficio una situación de riesgo o de peligro, debe cargar con los inconvenientes que dicha situación produce. (Valenzuela, 2004, p.310)

Junto con la teoría de riesgo creado surge la denominada teoría del riesgo profesional que "exige un grado de diligencia superior al promedio, referente a la competencia que cada uno debe tener para iniciar sus actividades" (Espinoza, 2016, p.189).

Espinoza (2016), al desarrollar las teorías que surgen en torno a la responsabilidad objetiva, señala que merece particular mención el criterio de riesgo empresa; así señala lo siguiente:

La responsabilidad deberá ser atribuida a quien tiene el control de las condiciones generales del riesgo y esté en grado de traducir el riesgo en costo, incorporándolo armónicamente en el juego de las ganancias y las pérdidas, con el instrumento del seguro o de autoseguro. Este riesgo, es el que inevitablemente acompaña el ejercicio de toda que presente un mínimo de continuidad y que requiera un mínimo de organización de hombres y medios (p.189). 
De la misma manera, algunos autores como es el caso de Fernández Cruz \& León (2005) han querido dar como fundamento de la responsbilidad objetiva la de "exposición al peligro, señalando que "el principio que sustentaría la responsabilidad sería desde la perspectiva del civil law, el siguiente: aquel que ejercita actividades peligrosas debe responder de todos los daños que tal actividad cause a terceros. Y ¿por qué? Porque es

\section{$\underline{\text { razonable pensar que el que desarrolla la actividad que genera el peligro es quien }}$} puede dominar o evitar los peligros creados (Negritas y subrayado es nuestro) (p.127).

De lo expuesto hasta el momento, y de las diversas teorías que buscan fundamentar la responsabilidad objetiva, sin perjuicio que nuestro código civil recoge la teoría de riesgo creado en el artícuo 1970 del Código Civil, cabe preguntarnos ¿Quién ha generado o introducido el riesgo en la vida social? ¿Quién está en mejores condiciones de asumir los gastos generados por el daño ocasionado? ¿Quién es el que obtiene el beneficio por el riesgo creado? ¿Quién puede dominar o evitar los peligros creados? Para algunas personas la respuesta es simple, el responsable es aquel que causó el daño, pero también lo podrá ser el propietario del bien, de ello no cabe duda, porque efectivamente éste puede estar en mejores condiciones de asumir los gastos generados del daño, o la persona cuyo dependiente ocasionó un daño a terceros pues dicha persona generó una situación que le genera un beneficio.

¿Podríamos decir lo mismo con relación a la empresa de leasing que es “formalmente propietaria del bien" por el solo mérito de la celebración del contrato de arrendamiento financiero? ¿Es posible afirmar que es la empresa de leasing quien genera un riesgo al introducir un bien riesgoso en la vida social? ¿No es acaso la empresa de leasing una mera intermediaria para facilitarle al arrendatario la utilización de bienes de capital o de equipos por carecer de capital necesario para su adquisición? Dichas preguntas serán resueltas más adelante al analizar el fundamento por el cual se imputa responsabilidad al propietario de un bien riesgoso o peligroso.

A modo de resumen podemos señalar que, la responsabilidad objetiva recogida en nuestro Código Civil se puede basar en los siguientes supuestos:

a. Situaciones de riesgo, que se podrían traducir en la siguiente fórmula: si se genera una situación riesgosa, se responderá por los daños ocasionados, independientemente del parámetro de conducta del agente dañante o de que haya obtenido un beneficio (art. 1970). 
b. Situaciones de ventaja, vale decir, si una persona genera una situación que le ofrece un resultado favorable o beneficio, tendrá que responder también por los daños que se ocasionen producto de dicha situación. Típicos ejemplos serían el de responsabilidad civil por el hecho del dependiente (art. 1981 c.c), el ser propietario de un animal (art. 1979 c.c) o el propietario de un edificio (art. 1980).

c. Situaciones legales individualizadas por el ordenamiento jurídico, como la de ser representante legal (art.1975 y 1976 c.c) (Espinoza, 2016, p.208).

\subsection{Responsabilidad del propietario del vehículo automotor según la Ley General de Transporte y Tránsito terrestre y su Reglamento:}

Habiendo analizado lo dispuesto en el artículo 1970 del Código Civil, resulta pertinente desarrollar todos aquellos dispositivos legales sobre responsabilidad civil derivada de accidentes de tránsito.

El Texto Único Ordenado (TUO) del Reglamento Nacional de Tránsito-Código de Tránsito, aprobado por Decreto Supremo No 016-2009-MTC, dispone en su artículo 271 lo relativo a la conducta peligrosa.

Artículo 271: "La persona que conduzca un vehículo en forma de hacer peligrar la seguridad de los demás, infringiendo las reglas del tránsito, será responsable de los perjuicios que de ello provengan".

De la misma manera, el Reglamento antes citado señala en su artículo 272 lo siguiente:

"Se presume responsable de un accidente al conductor que incurra en violaciones a las normas establecidas en el presente Reglamento".

Por su parte, la Ley General de Transporte y Tránsito Terrestre- Ley $\mathrm{N}^{\circ} 27181$, en su artículo 29 determina los alcances de la responsabilidad solidaria derivada de un accidente de tránsito, en los siguientes términos:

\footnotetext{
Artículo 29.- De la responsabilidad Civil

"La responsabilidad civil derivada de los accidentes de tránsito causados por vehículos automotores es objetiva, de conformidad con lo establecido en el Código Civil. $\underline{\text { El }}$ conductor, el propietario del vehículo y, de ser el caso, el prestador del servicio de transporte terrestre son solidariamente responsables por los daños y perjuicios causados". (Negritas y subrayado es nuestro)
} 
Con relación al artículo 29, antes señalado, el Tribunal Constitucional en el Expediente $\mathrm{N}^{\mathrm{o}}$ 0001-2005-PI-TC que declara infundada la demanda de inconstitucionalidad interpuesta por el Gobierno Provincial de Huarmey contra los artículos 29 y 30 de la Ley No 27181, Ley General de Transporte y Tránsito Terrestre, señala expresamente lo siguiente:

\section{$(\ldots)$}

25 (...) en nuestro ordenamiento jurídico subsisten dos criterios de responsabilidad civil -objetivo y subjetivo- bajo los cuales se genera el resarcimiento de los daños ocasionados, siendo incluso que de no haberse efectuado dicha mención en el cuestionado artículo 29, y por el sólo hecho de encontrarnos frente al uso de un bien riesgoso (vehículos automotores), opera en forma automática el criterio de responsabilidad objetiva consagrado en el artículo 1970 del Código Civil frente al perjudicado, a fin de lograr el resarcimiento correspondiente de acuerdo al daño causado.

26. En efecto, entiende este Tribunal que en situaciones en que ocurre un accidente de tránsito que causa un daño a la vida, la integridad o la salud de la persona resulta, por decir lo menos, conveniente indemnizarla, lo cual está plenamente justificado cuando un sujeto causa un daño de tal naturaleza. Si algo de constitucional se encuentra en el artículo 1970 del Código Civil es, precisamente, la reparación del daño, en la medida que con dicha protección se otorga dispensa a los derechos a la vida e integridad y a la salud, reconocidos por los artículos 2.1 y 7 , respectivamente, de la Norma Fundamental. De esta forma, sin duda, es posible cumplir con el objetivo primordial de la responsabilidad civil, cual es, auxiliar o beneficiar a la víctima a través de la reparación del daño que hubiere sufrido".

Con todo lo desarrollado hasta el momento, resulta totalmente claro, y así también lo entiende la sentencia del Tribunal Constitucional antes citada (Expediente $N^{\circ}$ 0001-2005PI-TC) que:

\section{$(\ldots)$}

19. En nuestra legislación se han recogido dos criterios en materia de responsabilidad civil (subjetiva y objetiva) aplicables a nivel contractual y extracontractual, a fin de procurar el resarcimiento de la víctima del daño causado por la conducta lesiva.

Asimismo, de conformidad con lo establecido en la Ley General de Transporte y Tránsito Terrestre, la responsabilidad derivada de accidentes de tránsito es una de carácter objetiva, siendo los vehículos automotores, bienes riesgosos propiamente dichos. 


\subsection{Análisis de la responsabilidad civil del propietario que actúa como arrendador}

financiero:

Lo que será materia de discusión en los puntos siguientes es dilucidar si en el caso de un arrendamiento financiero, el arrendador financiero, por su sola calidad de propietario, debe encajar en lo dispuesto en el artículo $29^{\circ}$ citado anteriormente o por tratarse de un contrato cuya naturaleza no es otra que la de un financiamiento, debe liberársele de responsabilidad.

El artículo 6 del Decreto Legislativo 299, que regula el arrendamiento financiero, establece que:

Artículo 6: Los bienes materia de arrendamiento financiero deberán ser cubiertos mediante pólizas contra riesgos susceptibles de afectarlos o destruirlos. Es derecho irrenunciable de la locadora fijar las condiciones mínimas de dicho seguro.

La arrendataria es responsable del daño que pueda causar el bien, desde el momento que lo recibe de la locadora. (Negritas y subrayado es nuestro).

Por su parte, el artículo 23 del Decreto Supremo N 559-84-EFC, Reglamento de Ley de Arrendamiento financiero, establece que:

Artículo 23: Para el efecto a que se refiere el segundo párrafo del artículo 6 de la Ley de arrendamiento financiero, corresponde a la arrendataria asegurar obligatoriamente a los bienes materia de arrendamiento financiero contra riesgos de responsabilidad civil frente a terceros (Negritas y Subrayado es nuestro).

Como se puede apreciar de las normas antes señaladas, sería el arrendatario quien debe asumir cualquier daño que pueda ocasionar el bien desde el momento que lo reciba de la locadora, pero ello ha sido interpretado de una manera distinta por nuestros tribunales, tal como lo veremos en el capítulo III del presente trabajo de investigación.

Antes de entrar de lleno al análisis de la diversa jurisprudencia que atribuye responsabilidad al arrendador financiero por su condición de propietario del bien, es importante encontrar el fundamento por el cual se le imputa responsabilidad objetiva al propietario mismo. El propietario responde no porque sea culpable sino porque es propietario, pero ¿Cuál es la razón por la cual se le imputa responsabilidad al propietario si este no fue el causante o tuvo culpa en el accidente?

Respecto a la calidad del agente al que le es imputable el daño por bienes riesgosos o peligrosos podrían desprenderse dos interpretaciones de la norma. 
La primera de ellas es que el artículo $1970^{\circ}$ se refiere directamente al que comete el daño, con lo cual en muchos casos el propietario del bien estaría excluido. Mientras que, bajo una segunda interpretación, podría afirmarse que el propietario en tanto entrega un bien riesgoso a un tercero para su uso también causa el daño. De esta manera si una persona alquila su automóvil a otra y está última atropella a alguien, tanto el que usaba el vehículo como el propietario serían responsables. La doctrina se inclina por la segunda interpretación en función de la teoría de difusión del riesgo (De Trazegnies F., 2003, p. $500)$.

Incluso, diversos autores tratan de esbozar una respuesta a las diversas interrogantes con relación a la responsabilidad del propietario, señalando que una tesis posible consiste en sostener que este se beneficia con su propiedad y consecuentemente debe asumir los riesgos que ella genere (teoría del riesgo) (De Trazegnies F. , 2016, p. 475). Sin embargo, el Dr. Fernando De Trazegnies, plantea la respuesta a dicha interrogante desde la perspectiva de la teoría de la difusión del riesgo.

En efecto, de acuerdo con la teoría de la difusión del riesgo, el propietario es responsable porque puede asegurarse y el seguro diluye el riesgo entre todos los asegurados. Se podría decir entonces que, el propietario está en mejor aptitud de asegurar los daños derivados de su propiedad, ello en la medida que tiene un mayor control sobre el bien. Por tanto, el fundamento de la responsabilidad y el traslado del peso económico del daño al propietario no se deben a un hecho ciego, sino a la capacidad de éste de diluir ese costo a través del seguro.

Siguiendo con lo indicado por De Trazegnies F. (2016): La teoría de la difusión del riesgo (...), excluiría de responsabilidad a tal "propietario registral" (y no real) por cuanto no se cumplen respecto de él las condiciones que justifican socialmente el traslado del peso económico del daño (posibilidad de asegurarse) (p. 492).

De la misma manera, Falla (1994) citando a Calabresi señala:

"En los supuestos de daños causados por las cosas inanimadas-bienes riesgosos (art. 1970) y caída de edificios (art. 1980)-, se ha imputado la pérdida al sujeto que usualmente se encuentra en mejor aptitud para contratar un seguro: el propietario del bien-quien está en condiciones de asegurarse a un menor costo, y cuenta con mavor acceso a información referida al riesgo y a los eventuales daños que se derivan de la utilización de dichos bienes. (...) (p.154) (Negritas y subrayado es nuestro). 
Por otro lado, Valenzuela (2004), indica que el asignar responsabilidad al propietario, a diferencia de lo que plantea Trazegnies, no obedece solamente a una razón de distribución del riesgo (...) La responsabilidad del propietario también cumple una función de deterrence. Mediante la responsabilidad solidaria podemos obtener una reducción de los costos primarios de accidentes. (p. 325).

A fin de sustentar su posición, Valenzuela (2004), citando al mismo Trazegnies al hablar de difusión de riesgo señala:

(...) Es indudable que el propietario de un automóvil puede contribuir más facilmente y a más bajo costo a evitar daños a peatones, que lo que pueden hacer los peatones mismos: los propietarios tienen un cierto control sobre la potencialidad riesgosa del automóvil; ya que están en aptitud de revisar periódicamente sus frenos y su dirección, usar llantas en buen estado, contratar choferes expertos, conducir a baja velocidad, etc" (p. 326).

En efecto, se traslada la pérdida a quien usualmente se encuentre en mejor condición para evitar la producción de los accidentes, ya sea siendo más diligente en su actuar, controlando el nivel de actividad desarrollada, inviertiendo en sistemas de seguridad o adoptando otras medidas parecidas (Falla, 1994, p.147).

Consideramos pertinente citar una jurisprudencia que hace referencia a la responsabilidad del propietario de un bien riesgoso, dicha jurisprudencia señala lo siguiente:

“...Los hechos de un bien riesgoso, son consecuencia de la actividad de quien los gobierna y domina, de tal manera que puede impedir que se produzcan, pues tales hechos pueden ser, ordinariamente previstos y evitados. (...) En consecuencia, cuando la sentencia de vista establece la responsabilidad del propietario del vehículo (que causó el daño) en aplicación de lo dispuesto en el Artículo mil novecientos setenta del Código Civil, ha practicado una interpretación correcta de la norma" (Casación N² 290299/Lima, publicada en el Diario Oficial El Peruano el 07-04-2000, págs. 5000-5001) (Negritas y Subrayado es nuestro).

Dicha jurisprudencia hace referencia a la responsabilidad del propietario del bien, alegando de una manera muy clara, que los hechos de un bien riesgoso son consecuencia de quien los gobierna y domina, que en efecto puede ser el propietario mismo, pues está en aptitud de prevenir los daños y evitarlos, pero ¿esta situación sucede con el arrendador financiero? 
Luego de haber explicado el fundamento por el cual se le imputa responsabilidad objetiva al propietario de un bien riesgoso, cabe hacernos las siguientes preguntas: iSe puede responsabilizar al arrendador financiero por ser formalmente propietario del bien otorgado en arrendamiento financiero? iEl arrendador financiero, en su condición de propietario, se encuentra en posibilidad o en mejor aptitud de asegurar los daños derivados de su propiedad o evitar la producción de accidentes?

La respuesta, a todas luces, es negativa, pues tal como lo hemos señalado, el arrendador financiero, es un mero intermediario que adquiere el bien a solicitud del propio arrendatario, y es él quien está en mejores condiciones de asegurarlo contra daños de responsabilidad civil. Incluso, es la propia norma (Art. 23 del Reglamento de Ley de Arrendamiento financiero) que señala que corresponde a la arrendataria asegurar obligatoriamente a los bienes materia de arrendamiento financiero contra riesgos de responsabilidad civil frente a terceros.

Si la propia norma lo señala, ¿Por qué la diversa jurisprudencia sobre la materia atribuye responsabilidad al arrendador financiero por su sola condición de propietario? ¿La norma que regula el contrato de leasing es lo suficientemente clara para deslindar de responsabilidad al arrendador financiero?

Vale la pena mencionar, la posición que asumen algunos autores con relación a la responsabilidad de la empresa de leasing frente a daños ocasionados a terceros, así Espinoza (2016), citando a Federico Mesinas Montero, señala:

"Lo ideal, (...) es que la empresa de leasing tenga responsabilidad frente al tercero, pero que pueda evitar enfrentarse a la obligación de indemnizar, cargando dicha responsabilidad la aseguradora", agregando que "a nosotros nos parece conveniente que sea la empresa de leasing la que soporte el pago de las primas, pues precisamente el seguro es el escudo de ésta ante la posibilidad de tener que responder objetivamente frente a terceros dañados. Además generalmente la empresa de leasing estará en mejor posición para asumir el riesgo por los daños que puedan producirse y para diluir los costos en sus operaciones económicas. En todo caso, es claro que finalmente tal empresa trasladará los montos de las primas al arrendatario, vía la renta a pagar" (p.654). (Negritas y subrayado es nuestro).

Como se aprecia de lo antes citado, la víctima siempre verá compensado el daño ocasionado, sin embargo, la empresa de leasing trasladará los costos que ello genere al 
arrendatario, y ello no hace mas que encarecer los costos de leasing automotriz en perjuicio de los propios usuarios de dicha figura de financiamiento.

De esta manera, y de lo expuesto hasta el momento podemos afirmar lo siguiente: la empresa de leasing no está en mejor posición para controlar y/o reducir el riesgo por los daños que puedan producirse y por tanto no se justifica atribuirle responsabilidad objetiva por su sola condición de "propietario formal del bien"; es claro que frente a la posición de la diversa doctrina y jurisprudencia peruana, que analizaremos a continuación, estamos perdiendo las ventajas del leasing como fuente de financiamiento, pues se encarece de por sí esta figura contractual en perjuicio de los arrendatarios.

\subsection{Conclusiones del capítulo:}

Con el desarrollo del presente capítulo hemos llegado a las siguientes conclusiones:

- La responsabilidad civil por bienes o actividades riesgosas o peligrosas se encuentra recogida en el artículo 1970 del Código Civil. La naturaleza de dicha responsabilidad es sin lugar a dudas objetiva, dado que no se requiere como factor de atribución que el agente actúe con dolo o culpa, sino que por el contrario debe verificarse únicamente (i) la existencia del daño, y (ii) la relación de causalidad adecuada entre el daño y el bien o actividad riesgosa o peligrosa que lo ha ocasionado.

- La responsabilidad objetiva recogida en el artículo 1970 del Código Civil se fundamenta en la teoría de riesgo creado, en la medida que si se genera una situación riesgosa, se responderá por los daños ocasionados, independientemente del parámetro de conducta del agente dañante o de que haya obtenido un beneficio.

- La Ley General de Transporte Terrestre y Tránsito-Ley N 27181, determina los alcances de la responsabilidad solidaria derivada de un accidente de tránsito, estableciendo solidaridad entre el conductor, el propietario del vehículo y, de ser el caso, el prestador del servicio de transporte terrestre. Dicha normativa establece 
que la responsabilidad derivada de accidentes de tránsito es una de carácter objetiva, siendo los vehículos automotores, bienes riesgosos propiamente dichos.

- La doctrina ha buscado dar respuesta a la imputación de responsabilidad del propietario del bien, planteando que es él quien está en mejores condiciones de asegurar los daños derivados de su propiedad, como consecuencia del control que ejerce sobre los bienes (teoría de la difusión social del riesgo); e incluso señalando que, es el propietario de un automóvil quien puede contribuir más facilmente y a más bajo costo a evitar daños a peatones pues cuenta con mayor acceso a información referida al riesgo y a los eventuales daños que se derivan de la utilización de dichos bienes.

- La empresa de leasing no está en mejores condiciones para reducir y/o controlar el riesgo por los daños que puede generar un bien riesgoso o peligroso, pues su naturaleza misma es la de ser una fuente de financiamiento, cumpliendo un papel de mera intermediaria en la operación y por tanto no se justifica atribuirle responsabilidad objetiva por su sola condición de propietario formal del bien. 


\section{CAPITULO II: ASPECTOS GENERALES DEL CONTRATO DE ARRENDAMIENTO FINANCIERO}

\subsection{Definición del Leasing o Arrendamiento Financiero:}

En la doctrina nacional y extranjera podemos encontrar diversas definiciones de leasing; en todas ellas encontramos elementos comunes que iremos dilucidando a fin de obtener una definición unánime del contrato de leasing que nos permita entender claramente esta figura.

Así tenemos a Bravo (2010) que citando al jurista argentino Luis Muñoz señala que por Leasing:

La entidad financiera se obliga a adquirir y entregar a su cliente bienes de capital para que los utilice durante un plazo previsto y en consideración a su función económica, obligándose el cliente a pagar un precio cierto en dinero a efectos de amortizar el valor de adquisición, asumiendo los riesgos y vicios, pudiendo adquirirlos una vez concluido el plazo estipulado por el valor residual pactado en el negocio, o devolverlos en buen estado de conservación previsto, al vencimiento del plazo de duración del negocio. (p. 310)

Por otro lado, Leyva (2003), citando a Amorós señala que:

Se considera al leasing como un contrato por el que una de las partes-empresa de leasingse obliga a adquirir de un tercero determinados bienes que la otra parte ha elegido previamente, contra el pago de un precio mutuamente convenido, para su uso y disfrute durante cierto tiempo, que generalmente coincide con la vida útil y fiscal del bien, y durante el cual el contrato es irrevocable, siendo todos los gastos y riesgos por cuenta del usuario, quien, al finalizar dicho periodo, podrá optar por la devolución de los bienes, concertar un nuevo contrato o adquirir los bienes por el valor residual preestablecido. (p. 750-751)

De la misma manera tenemos a Navarro (2003), que citando a De la Mata Almudena señala que:

El contrato de arrendamiento financiero, conocido como contrato de leasing, permite al arrendatario obtener del arrendador el uso y disfrute de un bien durante un periodo de tiempo establecido en el contrato y a cambio de una renta o pago fraccionado. La 
especialidad del contrato es que, llegado el término establecido, el arrendatario tiene derecho a optar por las siguientes opciones:

1. El arrendatario puede comprar el bien objeto del contrato (cláusula de opción de compra).

2. Puede prorrogar el plazo establecido en el contrato y continuar con el uso o goce temporal del bien.

3. El arrendatario puede acordar con el arrendador la venta del bien a un tercero participando en el precio de venta.

4. Por último, también puede restituir el bien al arrendador (p. 553).

Ahora bien, el Decreto Legislativo $\mathrm{N}^{\circ} 299$ en su artículo 1, define al arrendamiento financiero como el:

Contrato Mercantil que tiene por objeto la locación de bienes muebles e inmuebles por una empresa locadora para el uso por la arrendataria, mediante pago de cuotas periódicas y con opción a favor de la arrendataria de comprar dichos bienes por un valor pactado.

De las definiciones expuestas en los párrafos precedentes, se puede deducir que los aspectos característicos del contrato de leasing son los siguientes:

a) El arrendatario es quien elige el bien que ha de adquirirse y también elige al proveedor.

b) La propiedad del bien durante la vigencia del contrato de leasing corresponde al arrendador financiero.

c) El arrendador cede el uso y disfrute de un bien que ha adquirido por encargo y responsabilidad del arrendatario.

d) Como contraprestación por el uso del bien, el arrendatario entregará una suma de dinero, la cual asciende, normalmente, al equivalente de la vida útil del bien por el valor del mismo.

e) El arrendatario tiene la opción de compra al valor residual previamente pactado por las partes.

f) En el contrato de leasing podemos hablar de tres partes en el contrato, las cuales son el arrendador financiero, el arrendatario y el proveedor. 
En consecuencia, de las definiciones planteadas podemos señalar que el leasing es claramente un contrato de financiamiento, en el cual una de las partes del mismo (arrendatario) no tiene los recursos financieros suficientes para adquirir maquinaria, equipos o inmuebles previamente definidos por éste, por lo que acude a una entidad del sistema financiero para que financie la compra de los bienes requeridos por el arrendatario. Una vez aprobado el financiamiento, la entidad financiera o empresa de leasing los adquiere y los entrega a su cliente para su uso y disfrute, obligándose este último a pagar, durante un plazo determinado, una cantidad de dinero que cubra el valor de adquisición de los bienes, las cargas financieras y demás gastos, otorgándole una opción de compra al arrendatario sobre dichos bienes.

\subsection{Naturaleza Jurídica del Leasing:}

En torno a la naturaleza jurídica del leasing existen diversas teorías que buscan determinar la esencia del arrendamiento financiero. A continuación, pasaremos a detallar las más resaltantes, llegando a nuestra propia posición con relación a la naturaleza del contrato de leasing.

\subsubsection{Teoría del Arrendamiento:}

Esta teoría es una de las primeras en tratar de vislumbrar cuál es la verdadera naturaleza del leasing y la centra en el denominado contrato de arrendamiento. Cabe resaltar, que esta teoría ha recibido respaldo de la legislación comparada y tenemos como ejemplo de ello, a la legislación francesa del 02 de julio de 1966 y la belga del 10 de noviembre de 1967 que califican al leasing como "alquiler con promesa unilateral de venta". Asimismo, sin ir muy lejos, en el Perú, el Decreto Legislativo $N^{\circ} 212$ y el Decreto Legislativo 299 definen al leasing como "arrendamiento con opción de compra".

Sin embargo, cabe preguntarnos ¿podemos realmente equiparar el leasing con un arrendamiento? A fin de responder a dicha interrogante, primero debemos verificar lo señalado en el artículo 1666 de nuestro Código Civil que define al arrendamiento de la siguiente manera: "Por el arrendamiento el arrendador se obliga a ceder temporalmente al arrendatario el uso de un bien por cierta renta convenida". 
En ese sentido, la referida teoría señala que el bien puede ser dado en arrendamiento por el propietario del mismo o por quien tenga esa facultad respecto de los bienes que administra y no existe la posibilidad de que el arrendatario se convierta en propietario del bien (Bravo, 2010, p. 312).

De la misma manera la citada teoría señala que por el hecho de existir la opción de compra del bien materia del arrendamiento no puede desconocerse la esencia y preponderancia del arrendamiento en sí.

Rodrigo Escobar Gil critica esta postura, considera al leasing fuera del marco jurídico del arrendamiento; afirma si bien las formas poseen algunos elementos en común, el Leasing enmarca elementos esenciales (término inicial y cláusula de opción de compra), el arrendamiento carece de los elementos citados, y de faltar éstos, se desvirtúa el carácter económico financiero de la institución en colación (Bravo, 2010, p. 312).

De la revisión de la teoría aquí analizada, podemos advertir una serie de diferencias con el contrato de leasing. En principio, debemos preguntarnos ¿Qué finalidad práctica anima a una empresa a adquirir bienes a través de leasing?

Como indica Navarro (2003), con relación a la usuaria, esta pretende "obtener el máximo de utilidad económica posible, pero con la posibilidad latente de adquirirlos a su sola decisión y por un precio residual que es menor al precio del mercado" (p. 559). Resulta totalmente claro, que el arrendamiento no busca ello, ya que la usuaria en un contrato de leasing no es, ni desea ser, una mera poseedora, pues si así fuera le bastaría celebrar un contrato de arrendamiento, en el cual pagaría rentas periódicas menores sin asumir los costos y riesgos que implica el contrato de leasing.

Otra diferencia que podemos encontrar entre el contrato de arrendamiento y de leasing, es el significado del precio en cada uno de dichos contratos. En el arrendamiento, el pago de las rentas mensuales es claramente la contraprestación por el uso del bien; mientras que en el leasing:

El uso es solo uno de los elementos componentes de precio pagado, puesto que el precio incluye otras prestaciones adicionales al uso: la adquisición del bien y la eventual transferencia de propiedad por el valor residual pactado para la opción de compra (Navarro, 2003, p. 559).

Asimismo, en el contrato de arrendamiento financiero podemos apreciar una clara colaboración entre la usuaria y la empresa de leasing o entidad financiera lo cual es 
sumamente importante, pues ello es el punto de partida de dicha figura contractual, en la medida que la sociedad se compromete a adquirir el bien, previamente elegido por el usuario.

Como se puede apreciar, no podemos negar que el contrato de arrendamiento influye en el contrato de leasing, incluso de acuerdo a nuestro Código Civil, específicamente en el artículo 1677 se señala que: "El contrato de arrendamiento financiero se rige por su legislación especial y, supletoriamente, por el presente título y los artículos 1419 a 1425, en cuanto sean aplicables”. Efectivamente, el leasing y el arrendamiento tienen un punto en común, que es la puesta a disposición de los bienes en calidad de uso. Sin embargo, si nos centramos en la finalidad, función y efectos, ambas figuras contractuales distan mucho de ser similares.

\subsubsection{Teoría de la Compraventa:}

Los propulsores de esta teoría se centran básicamente en analizar la función económica que desempeña esta figura contractual a fin de equipararlo a una compraventa. En efecto, los teóricos consideran que mientras la empresa usuaria tiene interés en obtener la titularidad del bien pagando el precio en forma diferida, la empresa de leasing o entidad financiera persigue la finalidad de hacer producir su capital, con una garantía, que no es otra que mantener la propiedad del bien; ambos objetivos se cumplen con la celebración de una compraventa con reserva de propiedad.

Sobre el particular, Bravo (2010) señala que:

De acuerdo a esta teoría, entre la sociedad de Leasing que transfiere el uso y goce del bien y el usuario, existe un acuerdo en torno al bien y al precio. La voluntad real de las partes es celebrar una compraventa a plazos; la suma de los alquileres que el usuario debe satisfacer sobrepasa el valor del material nuevo facilitado, proporcionando un beneficio a la sociedad de leasing. Ídem, existe la cláusula de opción de compra a favor del usuario (p. 311).

De la misma manera, Leyva (2003), citando a Cuesta Rute, refiere que el contrato de leasing es: "una operación de crédito y el ánimo del empresario es el mismo que le lleva a convenir una compraventa; la diferencia está únicamente en el modo de financiarla” (p. 770). 
Como se puede apreciar, dicha teoría equipara el contrato de leasing a una compraventa a plazos con reserva de propiedad; sin embargo, se pueden advertir una serie de diferencias con dicho negocio jurídico.

En la compraventa a plazos con reserva de propiedad, lo único que se difiere en el tiempo es el precio del bien por el mismo vendedor; en el leasing en cambio, quien difiere el precio de venta no es el vendedor del bien sino más bien la empresa de leasing.

Por otro lado, y un aspecto relevante que consideramos diferencia a ambas figuras contractuales, es que, en la compraventa con reserva de propiedad, el comprador adquiere inmediatamente la propiedad con el pago de la última cuota del precio pactado; es decir, el comprador no va a emitir una nueva declaración de voluntad señalando que efectivamente desea ejercer la opción de compra, como sí sucede en el contrato de leasing. Se debe tener claro que, en el Leasing, sólo a partir del ejercicio de la opción se aplicarán las reglas de la compraventa y se producirán sus efectos.

Incluso se debe destacar que, al momento de la celebración del contrato de Leasing, la empresa usuaria (arrendataria), no tiene la posibilidad de determinar qué decisión le convendría adoptar al vencimiento del plazo contractual, ello suele evaluarse en la etapa de ejecución, por ello pensar que la única alternativa que tiene la empresa usuaria al final del plazo contractual es la de adquirir la propiedad de bien es equipararlo a una compraventa con reserva de propiedad y ello no es la finalidad del contrato de leasing, que en última instancia es financiar el uso de un bien y eventualmente, ser título para adquirir la propiedad de los mismos.

De todo lo expuesto podemos señalar que, no podemos equiparar la compraventa a plazos con reserva de propiedad al contrato de leasing, pues este último implica una relación de financiamiento especial y no una operación de financiamiento cualquiera. Es cierto que el contrato de leasing tiene elementos tanto del contrato de arrendamiento como del contrato de compraventa con reserva de propiedad pero se trata de una figura distinta con características propias y regulación especial.

\subsubsection{Teoría del Préstamo:}

Los autores que promulgan esta teoría destacan la naturaleza financiera del leasing. En ese sentido, se define al leasing “como técnica de crédito en la cual el prestamista ofrece 
al prestatario la locación de un bien unida a la promesa unilateral de venta” (Leyva, 2003, pág. 775).

Asimismo, Leyva (2003) citando a Giovanoli, señala que:

La calificación de préstamo debe mantenerse, puesto que hay una efectiva entrega de fondos a un tercero (fabricante/proveedor), hecha por orden del tomador. Es más, agrega el citado autor, el carácter puramente financiero se evidencia por la ausencia de una obligación positiva a cargo de la empresa dadora del credit-bail, respecto al bien financiado por medio de ese contrato de préstamo (p. 776).

En nuestra opinión, dicha teoría tiene muchas falencias y no refleja la real naturaleza del contrato de leasing. En efecto, en el contrato de mutuo la operación crediticia es de carácter directo, esto es que el mutuante se obliga a entregar al mutuatario una determinada cantidad de dinero o de bienes consumibles a cambio que se le devuelvan otros de la misma especie, calidad o cantidad, en cambio, en el contrato de leasing, el crédito se otorga de manera indirecta a través de la adquisición de un bien capital y la concesión del mismo en uso de la empresa usuaria. Como se aprecia, en el leasing no existe transferencia de propiedad, sino que ella permanece en el patrimonio de la empresa de leasing cumpliendo una finalidad de garantía del crédito otorgado.

¿Podríamos hablar entonces de un arrendamiento financiero de dinero? De ninguna manera, pues éste no es un bien identificable y en cuanto a los bienes consumibles, aún en el caso fueran identificados, ello resulta irrelevante pues el mutuatario está obligado a devolver otros bienes de la misma especie, calidad o cantidad, pero no los mismos. A diferencia de ello, en el leasing o arrendamiento financiero, si no se ejercita la opción de compra, se debe devolver el mismo bien que fue materia del contrato.

Como se advierte, tratar de equiparar un contrato de préstamo a un leasing no responde a la verdadera naturaleza de dicha fuente de financiamiento. Asimismo, en el supuesto negado que el leasing sea un préstamo de dinero nos preguntamos ¿Por qué la empresa usuaria (arrendatario) no compra directamente el bien una vez que la empresa de leasing le ha prestado dinero? Si ello fuera la finalidad ¿Por qué involucrar a la empresa de leasing en la adquisición de bienes, haciendo que ésta se relacione con el fabricante/proveedor? 
Con dichas preguntas, claramente podemos advertir que el Leasing no es un simple contrato de mutuo, donde su razón de ser es recibir dinero; el Leasing implica una operación mucho más compleja, donde se financia directamente la adquisición de bien o bienes. Para mayor claridad podemos señalar que el objeto del contrato de leasing es financiar el uso y eventual adquisición de bienes de capital.

\subsubsection{Nuestra posición:}

Con la descripción y amplia explicación de las diversas teorías que arroja nuestra doctrina no cabe duda que el leasing es una figura sui géneris, que si bien tiene elementos del contrato de arrendamiento y compraventa, tiene características propias que lo diferencian como tal.

En ese sentido y en nuestra opinión, el leasing es una fuente de financiamiento para aquellas empresas que no tienen la suficiente liquidez para adquirir bienes de capital, cuyas características propias hacen que se aleje del contrato de arrendamiento y compraventa con reserva de propiedad, propiamente dicho.

Esas características, dentro de las cuales podemos nombrar a la opción de compra y el valor residual, hacen que el leasing se diferencie de otras figuras jurídicas. Es decir, si bien toma elementos del arrendamiento y compraventa en su constitución y ejecución, suele diferenciarse de todos ellos, lo que lo hace una figura "unitaria con causa única".

Coincidimos con Leyva (2003) al señalar que el leasing, desde el punto de vista funcional:

Responde a una unidad causal, la cual va más lejos que las causas particulares de aquellos negocios o prestaciones aisladas. La causa del leasing no es otra que la de financiación, que se devela en la etapa de perfección como en la ejecución del contrato (pp. 781782) (Negritas y subrayado es nuestro).

\subsection{Características del Contrato de Arrendamiento Financiero:}

El contrato de arrendamiento financiero tiene una serie de características que lo definen como tal; sin embargo, hemos considerado pertinente desarrollar las más resaltantes:

a) Contrato nominado y típico: Tal como lo mencionamos anteriormente, en el Perú su regulación data de varios años atrás, es decir a partir del Decreto Ley 
$\mathrm{N}^{\circ} 22738$ del 24 de octubre de 1979, para posteriormente ser tratado tributariamente a través del Decreto Legislativo $\mathrm{N}^{\circ} 212$ y finalmente por la actual regulación contenida en el Decreto Legislativo $N^{\circ} 299$ del 26 de julio de 1984.

b) Es un contrato mercantil: De esa manera se encuentra regulado en el artículo $1^{\circ}$ del Decreto Legislativo 299. Suele llamarse también contrato de empresa, porque "los capitales destinados a inversiones en locación de equipos se practica por empresas especializadas, al punto que el Art. 2 de la Ley de Arrendamiento Financiero señala que cuando la locadora está domiciliada en el país deberá ser una empresa bancaria, financiera o autorizada por la SBS (Arias- Schreiber, 1999, pp. 105-106).

c) Contrato principal: En la medida que tiene vida propia no depende de ningún otro contrato celebrado con anterioridad.

d) Es autónomo: La doctrina señala que si bien está inspirado en otros contratos (como son los contratos de compraventa y arrendamiento), no constituye la suma de ellos, sino que tiene unidad propia. A fin de tener claro ello, consideramos pertinente citar a Arias- Schreiber (1999), quien a su vez cita al Dr. Manuel de la Puente y Lavalle:

Ocurre aquí en el campo del Derecho, algo similar a lo que ocurre en el campo de la Química, en que la unión de dos elementos, doble proporción de hidrógeno con una de oxígeno no da lugar a que haya suma de hidrógeno y oxígeno, sino que resulta un producto nuevo que no es hidrógeno ni oxígeno, sino que es agua (p. 105).

Este es un excelente ejemplo de lo que ocurre con el contrato de arrendamiento financiero o leasing, tiene elementos propios de otras figuras contractuales pero el resultado de la suma de tales elementos no origina que sea uno u otro ni mucho menos la suma de aquellos, sino más bien una figura totalmente nueva y autónoma. 
e) Contrato constitutivo y de prestaciones recíprocas: Es constitutivo en la medida que de dicho contrato se origina una situación jurídica, que no es otra que permitir el uso de los bienes muebles o inmuebles materia del contrato de arrendamiento financiero por parte de la arrendataria. Por otro lado, implica un contrato de prestaciones recíprocas pues para ambas partes contratantes (arrendador financiero y arrendatario) se generan derechos y obligaciones. Así, encontramos que tales derechos y obligaciones se encuentran regulados expresamente en la Ley de Leasing y su Reglamento, los cuales detallaremos someramente a continuación:

Como ejemplo, de los derechos de la arrendadora podemos citar: (i) Conservar la propiedad del bien objeto de leasing hasta la fecha en que surta efecto la opción de compra ejercida por la arrendataria; (ii) Exigir el aseguramiento de los bienes por parte de la arrendataria, (iii) Inspeccionar los bienes entregados a la arrendataria y exigirle las reparaciones y el mantenimiento respectivo, (iv) Cobrar cuotas periódicas fijadas en el contrato; (v) no responder por los vicios y daños que se produzcan o generen los bienes en uso de la arrendataria; entre otros. Como obligaciones de la arrendadora tenemos: (i) Celebrar un contrato con el fabricante o proveedor que le indique la arrendataria, ciñéndose a las especificaciones indicadas en el contrato de leasing; (ii) Respetar la opción de compra a favor de la arrendataria; (iii) Responder por la perturbación en el uso y goce pacífico del bien; entre otros.

Por su parte, la arrendataria tiene dentro de sus derechos el de hacer uso en cualquier momento de la opción de compra al precio y condiciones pactadas por las partes, exigir la entrega del bien y hacer uso del mismo en las condiciones establecidas en el contrato de leasing, entre otros. Dentro de sus obligaciones encontramos la contratar los seguros establecidos en el contrato, efectuar el pago de las cuotas periódicas, efectuar el pago del valor residual, en caso de ejercitar la opción de compra, responder por los daños y perjuicios que cause el bien o bienes a partir del momento en que los recibió, entre otros. 
f) Es oneroso: Pues ambas partes incurren en beneficios y gastos económicos tanto para su celebración como para su ejecución. Hay enriquecimiento y empobrecimiento correlativos.

g) Contrato Consensual: Con relación a esta característica hemos podido encontrar opiniones encontradas en la doctrina, pues por un lado tenemos a (Arias- Schreiber, 1999) quien expresamente señala que el contrato de arrendamiento financiero es uno formal y cuya formalidad está dada por el artículo 8 de la Ley de Arrendamiento Financiero, que exige escritura pública, la cual podrá inscribirse, a pedido de la locadora, en la ficha o partida donde se encuentre inscrita la arrendataria (p. 107).

Por su parte, Navarro (2003) señala que el "leasing se perfecciona con el simple acuerdo de voluntades, siendo necesaria la formalización por escritura pública precisándose que esta última únicamente constituye una formalidad ad probationem" (p. 563).

A fin de dilucidar tal controversia, hemos considerado pertinente citar el criterio expuesto en la sentencia expedida en el expediente $\mathrm{N}^{\circ}$ 2564-98/LIMA que a la letra dice:

Qué, el artículo ocho del Decreto Legislativo número doscientos noventinueve establece que el contrato de arrendamiento financiero se celebrará mediante escritura pública, empero su inobservancia no se encuentra sancionada con nulidad, por lo que, conforme a la norma referida en el párrafo anterior, se concluye que la formalidad establecida en el Decreto Legislativo aludido no es ad solemnitatem sino ad probationem. Sobre el particular debe tenerse presente que "en cuanto al carácter ad probationem de la forma (...), cuando la ley impone una forma y no sanciona con nulidad su inobservancia, constituye sólo un medio de prueba de la existencia del acto" (Vidal Ramírez, Fernando. Teoría General del Acto Jurídico. Lima: Cusco, mil novecientos ochenticinco, página ciento cuarenta).

A la luz de tal jurisprudencia, coincidimos con Navarro Palacios al señalar que el contrato de leasing es uno netamente consensual, siendo la elevación a escritura Pública una formalidad Ad probationem. Ahora bien, no podemos dejar escapar lo indicado por Navarro (2003), en el sentido que, si bien la 
formalidad es una ad probationem, "a través de la formalidad antes señalada, se podrá promover proceso ejecutivo exigiéndose las sumas que correspondan y la devolución del bien (p. 563).

h) Contrato de tracto sucesivo y de ejecución continuada: Pues prolonga su cumplimiento a través de un plazo dilatado y en la medida que las partes cumplen sus obligaciones periódicamente.

\subsection{Elementos del Contrato de Leasing:}

Hemos considerado pertinente dividir los elementos del contrato de leasing en subjetivos y objetivos, los mismos que desarrollaremos a continuación:

\subsubsection{Elementos Subjetivos:}

Algunos autores propugnan el carácter trilateral del contrato de arrendamiento financiero o leasing, pues consideran que el proveedor es parte del contrato, junto con el arrendatario y la empresa del sistema financiero.

A continuación, detallaremos cada uno de ellos:

a) El arrendatario: es el denominado cliente, interesado o beneficiario, quien puede ser una persona natural o jurídica que requiere financiamiento para el uso, disfrute, y eventualmente la adquisición de un bien o bienes (maquinaria, equipos o inmuebles) para el desarrollo de sus actividades económicas. El Decreto Legislativo $\mathrm{N}^{\circ} 299$ en su artículo $3^{\circ}$ lo denomina arrendatario.

b) Empresa del sistema financiero: empresa que otorga la financiación y en nuestra regulación actual se denomina locadora. Cabe precisar que, de acuerdo al artículo 2 del Decreto Legislativo 299: "Cuando la locadora esté domiciliada en el país deberá necesariamente ser una empresa bancaria, financiera o cualquier otra empresa autorizada por la Superintendencia de Banca y Seguros, para operar de acuerdo a Ley". Asimismo, es importante destacar que, las obligaciones de estas entidades son las de financiar la compra de bienes objeto 
del contrato directamente al proveedor elegido, para otorgarlo en arrendamiento y reconocerle al arrendatario la opción de compra.

c) El proveedor: surge una discusión en la doctrina, en el sentido si debe considerarse o no al proveedor como parte del contrato de arrendamiento financiero o leasing.

En la doctrina española, Díaz (2009) afirma:

$(\ldots)$

En el plano económico el "leasing" se plantea como una operación financiera que relaciona al proveedor, la sociedad de arrendamiento financiero y el usuario, en el plano jurídico se producen dos diferentes relaciones: de una parte, la que se establece entre el proveedor y la sociedad de arrendamiento financiero y de otra, la que vincula a esta última y al usuario. Así pues, el contrato de "leasing" se lleva a cabo únicamente entre la sociedad de arrendamiento financiero y el usuario, sin intervención alguna del proveedor, ello sin perjuicio de que previamente se haya celebrado otro contrato diferente entre aquélla y esta última (p. 1286).

Coincidimos plenamente con la doctrina que propugna únicamente la bilateralidad del contrato de leasing; sin embargo, nada obsta para que el proveedor sea incluido en el contrato, para efectos relativos a las garantías de los bienes vendidos, capacitación, asesoría técnica, venta de repuestos y otros de tipo técnico.

\subsubsection{Elementos Objetivos:}

Dentro de los elementos objetivos tenemos a los siguientes:

a) Cesión en uso por cierto tiempo: Tal como lo hemos señalado a lo largo del presente trabajo, en el contrato de leasing o arrendamiento financiero, el arrendador adquiere del proveedor el bien elegido por el arrendatario, cediéndole su uso, a cambio del pago de unas cuotas periódicas. En efecto, de acuerdo con la figura contractual materia de análisis, para el arrendador financiero, la propiedad del bien tiene una finalidad esencialmente de garantía y tal como indica Díaz (2009), siendo su interés mantenerse ajeno a las vicisitudes del cumplimiento del contrato de compraventa por parte del 
suministrador, que ha sido elegido por el usuario (p.1298). De la misma manera, se debe tener presente que el arrendatario asume los riesgos y vicios del bien, haciéndose responsable también, de su mantenimiento y conservación.

b) Opción de compra y precio: La doctrina es unánime en señalar que la opción de compra es un elemento consustancial al contrato de arrendamiento financiero a favor del arrendatario.

Sobre este elemento se debe precisar que, de conformidad con lo dispuesto en el artículo 7 de la Ley de Arrendamiento Financiero (Decreto Legislativo $\mathrm{N}^{\circ}$ 299):

\section{$(\ldots)$}

La opción de compra de la arrendataria tendrá obligatoriamente validez por toda la duración del contrato y podrá ser ejercida en cualquier momento hasta el vencimiento del plazo contractual. El ejercicio de la opción no podrá surtir sus efectos antes de la fecha pactada contractualmente. Este plazo no está sometido a las limitaciones del derecho común.

De la norma antes citada, tenemos que la opción de compra no es otra cosa que un contrato de opción se trata de un contrato preparatorio que forma parte del contrato de leasing y es un elemento intrínseco al mismo (Navarro, 2003, pág. 58).

Ahora bien, es de suma relevancia determinar qué se entiende por valor residual pues es claro que la opción de compra deberá ejercerse a dicho valor y no otro.

Por ejemplo, Arias- Schreiber (1999) señala que valor residual es aquella "diferencia entre el valor real del bien o bienes materia del contrato, debidamente fijado en el mismo y lo que se ha amortizado mediante el pago periódico de las cuotas que menciona el artículo 9 de la Ley peruana" (p. 112). Por su parte, Navarro (2003) citando a Farina, define el valor residual de la siguiente manera: 
El valor residual es el precio preestablecido con cuyo pago a la finalización del plazo de leasing, el tomador adquiere la propiedad del bien si hace uso de la opción fijada a tal efecto en el contrato.

$(\ldots)$

El valor residual es muy reducido con respecto al valor real del bien al momento de su pago. Para su fijación, habitualmente se tiene en cuenta parte de las sumas pagadas durante la locación como término medio (...) (p. 569).

Como se puede apreciar de ambos conceptos, la opción de compra no se ejercerá sobre el valor total del bien, sino más bien este valor se determina considerando el costo de adquisición menos la depreciación producto del uso, el transcurso del tiempo y la innovación tecnológica. Asimismo, tal como señala Navarro (2003), “dicho valor debe estar relacionado con los valores estimados al final del periodo de vida útil del bien en los términos pactados por las partes" (p.569).

\subsection{Modalidades de Leasing:}

De acuerdo a la doctrina nacional e internacional, el leasing suele clasificarse en diversas modalidades, ya sea por su finalidad (leasing operativo y financiero), por su ejecución (leasing directo o indirecto), por el objeto (leasing mobiliario e inmobiliario) y por el ámbito territorial de aplicación (nacional e internacional); sin embargo, hemos considerado conveniente centrarnos en las principales modalidades que detallaremos a continuación:

a) Leasing Operativo: Esta modalidad de leasing, suele diferenciarse del leasing financiero, en la medida que dicho contrato se celebra directamente con el fabricante, distribuidor o importador de bienes. Tal como señala Bravo (2010), "los bienes objeto del contrato son por lo común de uso corriente, de tal modo que pueden ser recolocados al término del contrato si éste no se renueva o no se compra el bien por el usuario" (p.314).

En consecuencia y en palabras de Navarro (2003), "el leasing operativo se observa cuando el arrendatario necesita el bien solo temporalmente, o cuando no sabe exactamente para cuanto tiempo se requiere el uso del bien” (p. 565). 
Finalmente, con relación a esta modalidad, debe señalarse que ésta es de corto plazo pues cubre un periodo menor que la vida útil promedio del bien.

b) Leasing financiero: Esta modalidad es la que hemos desarrollado a lo largo del presente trabajo, y tal como hemos señalado, a través de esta figura, el arrendatario selecciona al proveedor y los bienes que serán objeto del contrato y solicita a la empresa de leasing adquirir el bien elegido.

En efecto, Bravo (2010) indica con total claridad que:

Esta modalidad de leasing es aquella mediante la cual una empresa de leasing da en arrendamiento un bien determinado que ha elegido un usuario y que éste adquiere para tal propósito, obligándose el arrendatario a pagar un canon periódico, por un tiempo determinado e irrevocable, en el que ha asumido el arrendatario todos los riesgos y gastos de conservación de la cosa durante la vigencia del contrato en las condiciones que se acordaren o finalmente restituir el bien materia del contrato (p. 314).

c) Lease back: En esta modalidad, quien vende la maquinaria o equipos no es un tercero, sino el mismo sujeto que requiere que dichos bienes le sean arrendados. A través de esta figura, una empresa puede convertir sus activos fijos en efectivo y con ello solucionar sus posibles problemas de liquidez.

Con mayor sustento, Navarro (2003), indica que:

En esta modalidad, también conocida como "sale and leaseback", el sujeto que en un primer momento vende los bienes y luego los utiliza en calidad de arrendamiento, obtiene el derecho ejercitar el derecho de compra del referido bien al vencimiento del contrato y por un precio estipulado de antemano (p. $566)$.

\subsection{Ventajas del Leasing como fuente de financiamiento:}

En palabras de Peschiera Mifflin (2008), "el contrato de arrendamiento financiero favorece la circulación de la riqueza económica, porque se cede el uso y goce económico de un bien, y luego, transfiere la totalidad de los poderes económicos objetos del contrato" (p. 49). 
En efecto, tal como lo hemos indicado a lo largo del presente trabajo de investigación, la finalidad principal del leasing es permitir a las empresas adquirir bienes de capital cuando no cuentan con el efectivo necesario para hacerlo o que disponiendo de tales recursos buscan destinarlos a otra finalidad susceptible de mejorar su rentabilidad. De la misma manera, permite disponer rápidamente de activos, sin necesidad de hacer un desembolso propio de una compra, basta que se paguen las cuotas periódicas pactadas, con lo cual se puede hacer un importante ahorro de capital de trabajo.

A mayor abundamiento y para entender con mayor claridad la situación que se presenta cuando nos encontramos frente a un Leasing, Polar (2000) citando a Buonocore, señala lo siguiente:

"Si un sujeto tiene necesidad de un bien determinado, con características determinadas y no tiene los medios o bien la intención de inmovilizar capitales líquidos, ni de recurrir, aún teniendo la posibilidad, a los canales normales de financiación, puede dirigirse a la empresa de Leasing, requiriendo que le sea locado un bien de las características deseadas.

La empresa de Leasing-la cual desarrolla precisamente, desde un punto de vista económico, una función de intermediación-satisfará la pretensión del requirente, adquiriendo directamente en el mercado el bien o haciéndolo construir; y lo hará en función a su locación" (pp. 347-348) (Negritas y subrayado es nuestro).

Tal como lo cita Polar, desde el punto de vista económico, la empresa de leasing cumple una función netamente de intermediaria a fin de satisfacer la necesidad del arrendatario, y así también lo señala Ramos (2014), citando a Farina, al precisar que:

\section{(...) Este contrato no es otra cosa que un instrumento de financiamiento que}

relativiza la condición de propietario, bajo una óptica utilitarista en la que la calidad de poseedor, de usuario y beneficiario, resulta ser la primera línea de su función económica. Así, su origen puede explicarse en la necesidad de equipamiento de empresas, aunada con el rechazo a la deuda que inmovilice la circulación de capital (...) (Negritas y subrayado es nuestro).

De todo lo aquí señalado se puede colegir que, desde el punto de vista económico, el arrendamiento financiero es un mecanismo de financiamiento que, si bien se caracteriza porque la entidad financiera o empresa de leasing detenta la propiedad del bien otorgado en arrendamiento, esta no es más con una mera intermediaria que adquiere el bien a solicitud del propio cliente, y será este quien disfrute y haga uso del bien, asumiendo incluso todos los riesgos inherentes al mismo. 
Habiendo explicado meridianamente la naturaleza económica del contrato de arrendamiento financiero, a continuación, detallaremos las ventajas que conlleva celebrar un contrato de arrendamiento financiero, lo cual nos ayudará a comprender mucho mejor esta figura y a la vez entender por qué es tan importante que se cuente con una adecuada regulación que permita su desarrollo como fuente de financiamiento.

Cabe indicar que, los beneficios que puede generar un arrendamiento financiero no son solo para la empresa usuaria o mejor denominada arrendataria, sino también se reflejan para la arrendadora y a la vez para el proveedor.

Como ventajas del contrato de leasing, podemos señalar los siguientes y más importantes:

a) Financiamiento del $100 \%$ de la operación: si comparamos al leasing con un préstamo para la compra de un bien en una entidad bancaria o financiera, tenemos que este último no cubre el $100 \%$ del precio total del bien, sino más bien un $80 \%$ o $90 \%$, generando que el monto restante sea cubierto con recursos propios de la empresa usuaria. Es por ello, que dentro de los principales beneficios del leasing como fuente de financiamiento es que las empresas pueden financiar el $100 \%$ del valor del bien.

b) Elimina riesgos de obsolescencia: Citando a Navarro (2003), "la celebración de un contrato de leasing elimina riesgos de obsolescencia, pues la finalidad principal del arrendatario no es la adquisición del bien, sino la productividad que este significaría para el negocio" (p. 555).

c) Garantías: El bien objeto del contrato de leasing opera como garantía de la operación; esta ventaja es sumamente importante pues se eliminan los gastos de garantía como las existentes en operaciones de crédito en las que existe riesgo de insolvencia en el pago. Cabe mencionar que, el leasing es un buen negocio financiero para la empresa de leasing con una excelente garantía pues la propiedad del bien materia de arrendamiento financiero, no se transfiere hasta que se ejerza la opción de compra por parte del arrendatario, disminuyendo sobremanera el riesgo que puede generar la operación. 
d) Facilita la capitalización de las empresas: Tal como señala Navarro (2003), "esta forma de financiamiento sirve, por ejemplo para facilitar la adquisición de activos por parte de las empresas y lograr su capitalización, pues se trata de activos que se pagarán con los resultados que la empresa genere” (p. 555).

e) Flexibilidad de la contratación: esta ventaja se ve reflejada en el leasing, en la medida que corresponde al arrendatario seleccionar el bien y el proveedor; este realizará por su cuenta el estudio técnico del equipo y su compatibilidad con el funcionamiento de la empresa, y a su vez escoge entre las alternativas de mercado a aquel proveedor que le satisface su demanda, todo ello basado en sus necesidades. Una vez seleccionado el bien, el arrendatario pasará a fijar, junto con su contraparte, las condiciones de pago en función a su propio flujo de caja (Polar, 2000. p. 349).

f) Beneficios tributarios: El leasing constituye un importante escudo tributario pues la depreciación como el interés de las cuotas constituyen gasto deducible para efectos del impuesto a la renta, ello permite disminuir la utilidad y por tanto, el impuesto a la renta. Otro beneficio tributario proviene del hecho que el IGV de las cuotas periódicas constituye crédito fiscal.

Si bien el leasing cuenta con una serie de ventajas como fuente de financiamiento, la doctrina también ha desarrollado una serie de desventajas en caso se opte por esta figura contractual. La principal desventaja que suele desarrollar la doctrina es el alto costo financiero que puede acarrear esta operación. En efecto, (Polar, 2000), señala que:

"La razón de este elevado costo financiero es simple: debido a que estamos financiando una inversión por medio de un intermediario financiero, no solo debemos costear el valor del bien y los recargos financieros de aplazamiento de cuotas, los cuales pagaríamos en una inversión con dinero propio u otorgado por una operación de crédito; sino también debemos costear el margen de beneficio que la empresa solicitará para sí misma en la operación, en busca de su propia rentabilidad” (p. 351).

Sin embargo, a pesar de las desventajas que suele plantear la doctrina, el leasing como fuente de financiamiento, contiene una serie de ventajas, en comparación con otras 
fórmulas de financiación, que hace muy atractivo para las empresas optar por esta figura como alternativa incluso al crédito tradicional.

\subsection{Conclusiones del capítulo:}

Las principales conclusiones del capítulo, aquí desarrollado son las siguientes:

- El contrato de arrendamiento financiero es claramente un contrato de financiamiento que permite a una de las partes (arrendatario) adquirir bienes de capital cuando no cuentan con el efectivo necesario para hacerlo o que disponiendo de tales recursos buscan destinarlos a otra finalidad susceptible de mejorar su rentabilidad. Será la entidad financiera o empresa de leasing quien adquiera los bienes, previamente elegidos por el arrendatario para su uso y disfrute, otorgándole una opción de compra sobre dichos bienes.

- El leasing es una figura sui géneris, que si bien tiene elementos del contrato de arrendamiento y compraventa, tiene características propias que lo diferencian como tal. Es decir, si bien toma elementos del arrendamiento y compraventa en su constitución y ejecución, suele diferenciarse de todos ellos, lo que lo hace una figura "unitaria con causa única". La causa del leasing no es otra que la de financiación, que se devela en la etapa de perfección como en la ejecución del contrato.

- El leasing, desde el punto de vista económico, cumple una función de intermediaria que satisfará las necesidades del arrendatario al adquirir el bien para uso y disfrute de éste; sin embargo, esta figura como fuente de financiamiento relativiza de por sí la condición del propietario del bien, donde la propiedad no es más que una "garantía" de la operación y ello sustenta nuestra posición en el sentido que el arrendador financiero no debe asumir ningún tipo de responsabilidad frente a terceros por daños causados por el uso de bienes otorgados en leasing. 
- De la misma manera, se debe mencionar que el leasing como tal, contiene una serie de beneficios, dentro de los cuales encontramos, lograr un financiamiento del $100 \%$ de la operación, eliminar riesgos de obsolescencia, flexibilidad de la contratación, entre otros. Asimismo, son los beneficios tributarios que generan lo que atrae a las empresas para optar por esta fuente de financiamiento. 


\section{CAPITULO III: PROBLEMÁTICA JUDICIAL Y PROPUESTA DE SOLUCIÓN}

\subsection{Análisis de jurisprudencia peruana sobre responsabilidad civil del arrendador financiero por accidentes vehiculares.}

En los capítulos anteriores hemos analizado a detalle la naturaleza jurídica del contrato de leasing y sus principales características, quedando claro que estamos frente a un instrumento de financiamiento para aquellas personas que desean adquirir bienes de capital, generando grandes ventajas económicas, fomentando de esta manera la inversión.

De la misma manera, hemos advertido a lo largo de los capítulos precedentes que el arrendador financiero, por su sola condición de propietario del bien, no está en mejores condiciones para asumir los daños derivados de accidentes vehiculares pues no detenta el control sobre ellos y mucho menos podría prevenir los riesgos que su uso genera; incluso de la legislación que regula el arrendamiento financiero se advierte que el propósito de la misma consiste en atribuir los costos derivados del uso del bien al arrendatario por lo que, el arrendador tendrá el derecho a exigir que este contrate a una empresa de seguros para que asuma el valor de los daños a terceros.

Sin embargo, a pesar que nuestro sistema jurídico dispone que la arrendataria es responsable del daño que pueda causar el bien desde el momento que lo recibe de la locadora y corresponde a ella asegurar obligatoriamente los bienes contra riesgos de responsabilidad civil frente a terceros; el Poder Judicial se pronuncia atribuyendo responsabilidad civil a las empresas de arrendamiento financiero en los casos de accidentes vehiculares, por su calidad de propietaria de los bienes entregados en leasing.

Cabe destacar, que los órganos de menor jerarquía, como son los Juzgados Civiles y Cortes Superiores resuelven, en algunas oportunidades, excluyendo de responsabilidad al arrendador financiero, bajo los argumentos que señalaremos más adelante.

Podemos señalar entonces, que el problema radica en la interpretación que suelen dar nuestros operadores de justicia al aplicar lo dispuesto en el artículo 29 de la Ley General de Transporte y Tránsito Terrestre, que dispone que el conductor, el propietario del vehículo $y$, de ser el caso, el prestador del servicio de transporte terrestre son 
solidariamente responsables por los daños y perjuicios causados. Nuestros Tribunales, al analizar las demandas de indemnización por responsabilidad extracontractual generadas por accidente vehiculares y emitir sus pronunciamientos no toman en cuentan ni analizan a profundidad la naturaleza jurídica y económica propia del arrendamiento financiero.

En ese sentido de la revisión de la diversa jurisprudencia peruana sobre la materia, hemos podido advertir tres argumentos que utiliza nuestro Poder Judicial a fin de sustentar sus pronunciamientos imputando responsabilidad civil al arrendador financiero y los cuales detallamos a continuación:

(i) El artículo 6 del Decreto Legislativo 299 si bien establece la responsabilidad de la arrendataria en el contrato de leasing de los daños que pueda causar el bien objeto del mismo, tal norma está destinada a regular el contrato de leasing y las relaciones (entiéndase derechos y obligaciones) que se dan entre las partes que lo celebran y no a regular los supuestos de responsabilidad extracontractual ni a limitar o determinar quién resulta responsable o quién debe resarcir un evento dañoso frente a terceros ajenos a tal acto. (Subrayado y negritas es nuestro).

(ii) La responsabilidad extracontractual del arrendador financiero también se verifica en el propio contrato celebrado entre las partes pues se suele establecer que si el Banco o empresa de leasing es obligado a asumir reparaciones, el cliente debe reembolsarle los mismos, y esto no es más que un reconocimiento de su responsabilidad.

(iii) Ante accidentes ocasionados por vehículos automotores resulta de aplicación lo dispuesto en el artículo $29^{\circ}$ de la Ley $N^{\circ} 27181$ - Ley General de Transporte y Tránsito Terrestre, que establece la responsabilidad solidaria entre el propietario y conductor del vehículo, aplicándose así el principio de especialidad normativa.

A continuación, analizaremos tres pronunciamientos de la Sala Civil Transitoria de la Corte Suprema de Justicia de la República que recoge los argumentos antes señalados. 
a) Casación 2388-2003 (LIMA):

La resolución data del 13 de julio de 2004 y la casación fue interpuesta por el Banco Banex en liquidación contra la sentencia de vista emitida por la Primera Sala Civil de la Corte Superior de Justicia de Lima. El Banco Banex en su recurso de casación denuncia la inaplicación del artículo sexto parte final del Decreto Legislativo 299, Ley de Arrendamiento Financiero, pues alega que tratándose de un caso en que el vehículo causante del daño constituye un bien que ha sido objeto de un contrato de arrendamiento financiero, la Sala Superior debió aplicar la norma denunciada para resolver la Litis, la cual establece que es el arrendatario quien responde por los daños y perjuicios que cause el bien o bienes a partir del momento en que los recibió; en ese sentido al tratarse de un bien entregado en arrendamiento financiero, por mandato legal, la responsabilidad por los daños que ocasione dicho bien se traslada del propietario arrendador al arrendatario.

En dicha Casación, se señala expresamente que se encontraba demostrado en autos que los demandados habían celebrado un Contrato de Arrendamiento Financiero, en virtud del cual los arrendatarios asumían la obligación de responder por los daños que causen con el bien objeto del contrato mientras este se encuentre bajo su posesión y riesgo, habiéndose contratado por intermedio del Banco la póliza con Popular y Porvenir Compañía de seguros con una cobertura por responsabilidad civil hasta un máximo de veinte mil dólares americanos.

A pesar del reconocimiento del contrato de arrendamiento financiero y la responsabilidad de los arrendatarios, la Sala Civil Transitoria invoca la Casación $\mathrm{N}^{\circ}$ 3622-2000 3 y declara INFUNDADO el recurso de casación interpuesto por el Banco Banex, siendo sus conclusiones las siguientes:

\footnotetext{
${ }^{3}$ Casación $N^{\circ}$ 3622-2000 (LIMA) del 21 de marzo de 2001 establece lo siguiente:

“...establece la responsabilidad de la arrendataria en el contrato de leasing de los daños que pudiera causar el bien objeto del mismo, tal norma está destinada a regular el contrato de leasing y las relaciones (entiéndase derechos y obligaciones que se dan entre las partes que lo celebran y no a regular los supuestos de responsabilidad extracontractual ni a limitar o determinar quién resulta responsable o quién debe resarcir un evento dañoso frente a terceros ajenos a tal acto, lo que se encuentra fuera de su marco y no constituye su finalidad..."
} 
“a) El artículo sexto parte final de la Ley de Arrendamiento Financiero rige a las relaciones internas que se establece entre las partes que suscriben el contrato de arrendamiento financiero, b) en consecuencia, sus alcances corresponden a la esfera de las relaciones contractuales y, en materia de responsabilidad civil, únicamente a la responsabilidad contractual, c) por tanto, la norma citada no resulta aplicable cuando nos encontramos ante hechos probados que generan responsabilidad extracontractual frente a terceros que no han intervenido en el contrato de leasing, sin perjuicio de que el propietario del vehículo, en virtud del citado artículo sexto, y a lo expresamente pactado en el contrato respectivo, pueda repetir lo pactado contra aquél que está llamado a asumir responsabilidad contractual, es decir el arrendatario, siendo que la responsabilidad civil extracontractual del codemandado Banco Banex se regula por las normas del Código Civil (artículos 1970 y 1983 y otros).

Los argumentos esgrimidos por la Sala Civil Transitoria distan mucho de lo regulado efectivamente en la Ley de Leasing y su Reglamento, dicha interpretación es muy antojadiza por parte de los tribunales, pues de ninguna manera lo establecido en el artículo 6 del Decreto Legislativo 299 rige las relaciones internas que se establecen entre las partes al suscribir un contrato de arrendamiento financiero. El citado Artículo 6 debe ser analizado conjuntamente con lo dispuesto en el artículo 23 del Reglamento de la Ley de Leasing que dispone que:

Para el efecto a que se refiere el segundo párrafo del artículo 6 de la Ley de arrendamiento financiero, corresponde a la arrendataria asegurar obligatoriamente a los bienes materia de arrendamiento financiero contra riesgos de responsabilidad civil frente a terceros.

Por tanto, en nuestra opinión, los argumentos empleados por la Sala Civil no son suficientes ni valederos para imputar responsabilidad al arrendador financiero por daños a terceros derivados del uso de vehículos automotores.

b) Casación $\mathrm{N}^{\circ}$ 1032-2004 (LIMA):

La resolución data del 20 de julio de 2005 y se trata de la casación interpuesta por Citileasing Sociedad Anónima quien alega fundamentalmente, la interpretación errónea del artículo 6 del Decreto Legislativo 299, indicando 
que la Sala Superior en sus considerandos sétimo y octavo pareciera entender que el artículo seis de la ley, regulase únicamente la relación jurídica contractual del arrendador y arrendatario financiero, más no los supuestos de responsabilidad civil frente a terceros. Asimismo, Citileasing señala que la empresa arrendadora tan solo financia la adquisición de un bien de capital y la Sala desconoce las funciones de la responsabilidad civil, eleva los costos del arrendamiento financiero en perjuicio de los propios terceros y peca de ingenua; la interpretación correcta es la que concluye que el arrendador no es responsable frente a terceros por los daños que cause la arrendataria con el bien.

En dicha Casación se precisa que la recurrente, celebró un contrato de arrendamiento financiero con la empresa de transportes Línea Interprovincial de Transportes Sociedad Anónima, respecto del vehículo que se vio involucrado en el accidente, el mismo que era conducido por un trabajador de la empresa antes aludida.

La Corte Suprema declaró INFUNDADO el recurso de Casación bajo los siguientes argumentos:

"Duodécimo: Que, en el caso de la legislación peruana el artículo mil novecientos ochentiuno del Código Civil prescribe que, aquel que tenga a otro bajo sus órdenes responde por el daño causado por este último, si ese daño se realizó en el ejercicio del cargo o en cumplimiento del servicio respectivo. El autor directo y el autor indirecto están sujetos a responsabilidad solidaria; siendo esto así, el legislador peruano ha entendido que se justifica la atribución de responsabilidad objetiva, a quien no ha estado, físicamente, en el suceso del tránsito, pero se encuentra ligado al sujeto que directamente se ha visto involucrado en el accidente, atendiendo a la teoría de difusión social del riesgo la cual entiende que "(...) el principal responde porque, dado que realiza una actividad económica, tiene la posibilidad de difundir más fácilmente, a través del sistema de precios el costo de accidentes inevitables que se presentan en todo proceso productivo de bienes y servicios. Por consiguiente, no es que el principal sea "culpable" -real ni presuntamente-sino simplemente es el mejor vehículo para diluir estos costos sociales (...); por ende, tanto la empresa arrendadora, propietaria del bien, de acuerdo con el contrato de leasing, como la empresa usuaria, son responsables del suceso de tránsito. 
En primer lugar, la Corte Suprema, a fin de sustentar su posición e imputar responsabilidad a la empresa de leasing, hace referencia al artículo 1981 del Código Civil (responsabilidad vicaria) para luego citar la denominada teoría de la difusión social del riesgo, argumento que más allá de generar confusión y ser aplicado de manera errada, pues tal como lo hemos mencionado en el capítulo primero del presente trabajo de investigación, la empresa de leasing no está en mejores condiciones para reducir y/o controlar el riesgo por los daños que puede generar un bien riesgoso o peligroso, no sustenta de manera contundente y con precisión el porqué el propietario del bien en un contrato de leasing podría ser responsable por los accidentes generados por el uso del bien riesgoso o peligroso.

Por su parte, la Corte Suprema, pareciera otorgar validez al contrato de arrendamiento financiero, respetando lo dispuesto por las partes en el mismo contrato, al señalar lo siguiente:

“( $\ldots)$

Décimo Cuarto: (..) el arrendamiento financiero es un contrato mercantil, en cuyo texto normativo, contenido en el Decreto Legislativo número doscientos novetinueve, de fecha veintiséis de julio de mil novecientos ochenticuatro, no aparecen disposiciones jurídicas de orden público, cuya inobservancia este sancionada expresamente con la nulidad del acto, lo que quiere decir que por su naturaleza, y atendiendo a su texto normativo, la institución del arrendamiento financiero, permite la adecuación de las normas establecidos a los intereses de las propias partes y de sus actividades económicas; Décimo Quinto-- Que por ende, no se puede desconocer o minimizar la importancia del propio contrato de arrendamiento financiero, en el ítem referido a la responsabilidad civil, derivada del uso del bien arrendado y de los alcances que las propias partes le podrían haber atribuido, de acuerdo a sus intereses, a la última parte del artículo sexto del Decreto Legislativo $\mathbf{N}^{\circ}$ doscientos noventinueve" (Negritas y subrayado es nuestro).

Sin embargo, la Corte Suprema señala que tanto la empresa arrendadora, propietaria del bien, como la empresa usuaria, son responsables civiles del suceso de tránsito, pues la cláusula décima del contrato de arrendamiento financiero señala que “(...) cualquier pago que Citileasing efectúe en su calidad de propietario por daños causados por terceros con ocasión del 
uso del bien, deberán serle reembolsados por la arrendataria". Para la Corte Suprema, ello es un acuerdo de partes para asumir la responsabilidad solidaria entre los codemandados respecto de la víctima. Es interesante citar lo señalado por la Corte Suprema en este punto:

“(...) carece de sustento plantear la interpretación errónea de una norma, cuando las partes por el común acuerdo de sus voluntades materializado en un contrato, y de acuerdo con la ley de la materia que les permite el pacto en contrario, ha modificado ejercitando su derecho a la libertad contractual, lo prescrito en la norma, flexibilizando el sistema de responsabilidad civil y el riesgo del uso del bien".

Como argumento final para imputar responsabilidad solidaria al propietario del bien, la Corte Suprema señala que el suceso de tránsito habría ocurrido el 26 de noviembre de 1998, esto es cuando estaba vigente el Decreto Legislativo $\mathrm{N}^{\circ}$ 420 (Código de Tránsito y Seguridad Vial), que expresamente señalaba lo siguiente:

“(...) el propietario del vehículo instrumento de un accidente, asumirá solidariamente con el conductor la responsabilidad civil por los daños personales o materiales que este último hubiera ocasionado a terceros $(\ldots)$ ”.

En nuestra opinión, el considerar que el arrendador financiero es responsable por el sólo mérito de haber señalado en el contrato de arrendamiento financiero que el cliente debe reembolsarle todos aquellos gastos que efectúe en su calidad de propietario por daños causados por terceros con ocasión del uso del bien, no tiene ningún asidero legal; dichas disposiciones en los contratos no hacen más que demostrar que debido a los reiterados pronunciamientos judiciales, el arrendador financiero le traslada todos los costos al arrendatario encareciendo mucho más esta importante fuente de financiamiento como es el leasing.

c) Casación 1188-2011 (LIMA):

La resolución, también de la Sala Civil Transitoria, data del 27 de enero de 2012, y se trata del recurso de Casación interpuesto por la demandada Empresa Financiera TFC S.A contra la sentencia de vista emitida por la Primera Sala Civil de la Corte Superior de Justicia de Lima. La Empresa Financiera TFC 
S.A. invocó la causal de infracción normativa del artículo 6 del Decreto Legislativo $\mathrm{N}^{\circ} 299$, señalando que los artículos 1970 del Código Civil y 2 del Reglamento Nacional de Responsabilidad Civil y Seguros Obligatorios por Accidentes de Tránsito, serían aplicables al presente caso, en tanto no existiera una norma especial; sin embargo, al estar frente a un arrendamiento financierocuya regulación es diferente-donde la recurrente tiene la calidad de locadora del vehículo con el que se causó el daño, se le excluye de toda responsabilidad, a razón de la libertad contractual que le asiste.

La Sala Civil Transitoria, resuelve el presente caso declarando INFUNDADO el recurso de casación bajo los siguientes argumentos:

(...) SEXTO.-Que, si bien el artículo 6 del Decreto Legislativo número 299, establece que la arrendataria es responsable del daño que pueda causar el bien, desde el momento que lo recibe de la locadora, empero, no se puede soslayar la Ley General de Transporte y Tránsito Terrestre número 27181, en su artículo 29 que señala textualmente: "La responsabilidad civil derivada de los accidentes de tránsito causados por vehículos automotores es objetiva, de conformidad con lo establecido en el Código Civil. El conductor, el propietario del vehículo y, de ser el caso, el prestador del servicio de transporte terrestre son solidariamente responsables por los daños y perjuicios causados. SÉTIMO.- Que, el Principio de Especialidad, supone que "la disposición especial prima sobre la general, es decir, si dos normas con rango de Ley confluyen y establecen disposiciones contrarias, una referente a un aspecto general y otra al aspecto más especial y restringido, primará la especial, pues ante la concurrencia aparente de normas sobre una materia, tendrá la norma especial, validez sobre la general".

La Sala Civil Transitoria de la Corte Suprema, resuelve señalando que aun cuando medie un contrato de arrendamiento financiero, ello no enerva la responsabilidad de la Empresa Financiera TFC S.A. por los daños ocasionados, tomando en consideración el llamado Principio de Especialidad, por lo que prima la ley especial y en este caso el artículo 29 de la Ley 27181.

A diferencia de las casaciones citadas en los literales a) y b) anteriores, en la presente casación se hace referencia expresamente al principio de especialidad y de acuerdo a la Corte Suprema, prima la Ley General de Transporte y Tránsito Terrestre por tratarse de un accidente vehicular en desmedro de la 
propia Ley de Leasing y su Reglamento. Consideramos pertinente ahondar un poco más en el denominado principio de especialidad y citando a Tardío (2003) podemos aprecia que:

El principio de especialidad normativa-como destaca N.Bobbio-hace referencia a la materia regulada, el contenido de la norma, y supone el tránsito de una regla más amplia, que afecta todo un género, a una regla menos extensa, que afecta exclusivamente a una especie de dicho género. (...) Se destaca en la misma línea que la norma que representa el género y la que regula la especie posee elementos comunes, pero la norma especial añade un dato ulterior a la que representa el género. (p. 191)

Siguiendo a Tardío (2003) resulta pertinente señalar que:

La Ley especial se aplicará con preferencia a la Ley general cuando su supuesto de hecho se ajusta más al hecho concreto, pues de otra forma quedaría ineficaz, ya que nunca sería aplicable y no puede suponerse que el legislador quiso una lex sine effectu. Y, por el contrario, la ley general se aplicará a todos los supuestos no encuadrables en la ley especial y será, por tanto, también eficaz en su ámbito (p. 193).

Como podemos apreciar, el principio de especialidad como principio general de derecho implica que "Ley Especial prima sobre la Ley General"; sin embargo, centrándonos en la figura de leasing, cabe preguntarnos ¿Cuál es la norma que prima al imputar responsabilidad civil al arrendador financiero por accidentes vehiculares? Tal como lo hemos mencionado en los capítulos precedentes, el contrato de arrendamiento financiero es un contrato típico regulado por una Ley Especial como es el Decreto Legislativo 299 y su Reglamento; incluso el propio Código Civil, señala en su artículo 1677 del Título VI-Arrendamiento- que; "El contrato de arrendamiento financiero se rige por su legislación especial y, supletoriamente, por el presente título y los artículos 1419 y 1425; en ese sentido en aplicación del principio de especialidad, somos de la opinión que son el Decreto Legislativo $\mathrm{N}^{\circ} 299$ y su Reglamento, los que deben primar sobre la Ley General de Transporte y Tránsito Terrestre- Ley $\mathrm{N}^{\circ} 27181$; sin embargo nuestros tribunales no lo han interpretado de esa manera, siendo de suma importancia proceder con la 
modificación de las diversas normas que puedan ser contrarias a lo dispuesto en la Ley de Leasing y su Reglamento.

Habiendo citado la diversa jurisprudencia que atribuye responsabilidad civil al arrendador financiero en el caso de accidentes de tránsito, es menester citar algunos pronunciamientos judiciales que no responsabilizan al arrendador financiero frente a daños ocasionados por los bienes otorgados en arrendamiento financiero; como lo hemos señalado anteriormente, a nivel de Corte Suprema, dichos pronunciamientos son nulos, y son más bien los jueces de primera instancia y las Cortes Superiores que aplican lo dispuesto en la Ley de Leasing y su Reglamento.

A modo de ejemplo, podemos citar lo señalado en la sentencia del 29 Juzgado Especializado en lo Civil de Lima, recaída en el expediente $N^{\circ}$ 07016-2007-0-1801-JRCI-29, que a la letra dice:

"VIGÉSIMO.- Que, respecto de la codemandada Volvo Finance Perú S.A. (Hoy Financiera TFC S.A.) debemos tener en cuenta lo normado en el artículo 6 del Decreto Legislativo $\mathrm{N}^{\circ} 299$, que establece que, los bienes materia de arrendamiento financiero deberán ser cubiertos mediante pólizas contra riesgos susceptibles de afectarlos o destruirlos. Es derecho irrenunciable de la locadora fijar las condiciones mínimas de dicho seguro. La arrendataria, según la citada norma, es responsable del daño que pueda causar el bien, desde el momento que lo recibe de la locadora; VIGÉSIMO PRIMERO.(...) en tal sentido, siendo la arrendataria la que tenía en uso el vehículo en momento del accidente brindando servicio interprovincial, a tenor de la última parte del artículo $6^{\circ}$ del Decreto Legislativo $\mathrm{N}^{\circ} 299$, corresponde a la citada empresa de transportes responder exclusivamente por el daño causado por el vehículo; consecuentemente, respecto de esta codemandada la demanda debe ser desestimada." (Negritas y subrayado es nuestro).

Coincidimos totalmente con dicho pronunciamiento pues el Juzgado Civil consideró que, al tratarse de un arrendamiento financiero debía aplicarse el artículo 6 de la Ley de Leasing y siendo el arrendatario quien se encontraba en uso del bien al momento del accidente es este quien debía responder por los daños ocasionados. Cabe precisar que, dicho proceso judicial llegó hasta la Corte Suprema, siendo el pronunciamiento final el que señalamos en el literal c) anterior, es decir la Casación 1188-2011 (LIMA), cuyos argumentos ya conocemos. 
Por otro lado, a nivel de Corte Superior tenemos el pronunciamiento de la Tercera Sala Civil de la Corte Superior de Justicia de Lima expedido con fecha 09 de octubre de 2012, que declaró improcedente la demanda de indemnización por daños y perjuicios contra el banco BBVA Continental, citado en la Casación $N^{0}$ 2025-2013, que señala expresamente lo siguiente:

“(...) d) El artículo 6 del Decreto Legislativo $\mathrm{N}^{\circ} 299$, define que la arrendataria es responsable del daño que pueda causar el bien desde el momento que lo recibe de la locadora; dicho artículo en realidad regula la responsabilidad extracontractual frente a terceros en el contrato de leasing, debiendo entenderse que quien debe responder por los daños a terceros es la empresa usuaria desde el momento en que toma posesión del bien otorgado en leasing pues atendiendo a la naturaleza jurídica de este tipo de contratos, lo contrario implicaría desincentivar su aplicación en nuestro sistema; e) El Banco no resulta responsable por el daño ocasionado a la demandante, sino que el juicio de responsabilidad debe efectuarse solo respecto de la empresa de Transportes Tenorio Empresa Individual de Responsabilidad Limitada, debiendo declarase improcedente la demanda respecto de la entidad bancaria." (Negritas y subrayado es nuestro).

La interpretación dada por la Corte Superior es sumamente acertada y con la cual coincidimos totalmente pues el artículo 6 de la Ley de Leasing, regula la responsabilidad extracontractual frente a terceros y no las relaciones internas entre las partes como ha interpretado la Corte Suprema en sus múltiples pronunciamientos.

Cabe recalcar que, la Casación 2025-2013 declaró fundado el recurso de casación interpuesto por la empresa de Transportes Transler Empresa Individual de Responsabilidad Limitada, aplicando el principio de especialidad, señalando que prima lo dispuesto en la Ley General de Transporte y Tránsito Terrestre $\mathrm{N}^{\mathrm{o}} 27181$, y por tanto el Banco Continental debe responder de manera solidaria con la referida Empresa de Transportes.

De todo lo aquí señalado y de la jurisprudencia citada, podemos concluir que el problema principal radica en la interpretación sistemática que suele dar el Poder Judicial a la normativa vigente en nuestro país, aplicando el artículo 29 de la Ley General de Transporte y Tránsito Terrestre $\mathrm{N}^{\mathrm{o}}$ 27181, citado a lo largo del presente trabajo, y que atribuye responsabilidad solidaria al propietario del bien por los daños y perjuicios 
causados en el caso de accidentes vehiculares; ello sin considerar la naturaleza jurídica propia del leasing como fuente de financiamiento.

\subsection{Legislación comparada:}

A fin de poder plantear una solución adecuada a la problemática descrita en el presente capítulo, revisaremos legislación extranjera que nos permita realizar aportes sólidos para una adecuada regulación en materia de responsabilidad civil del arrendador financiero por accidentes vehiculares, todo ello orientado en la naturaleza jurídica del contrato de arrendamiento financiero.

\section{- Argentina:}

Con relación a la legislación comparada, tenemos en primer lugar a Argentina que reguló el contrato de leasing a través de la Ley 24.441 referido a Financiamiento de la Vivienda y Construcción, promulgada el 09 de enero de 1995. En dicha ley se reguló, entre otras figuras, al fideicomiso y leasing, siendo este último recogido en el Título II denominado “Contrato de Leasing”. Posteriormente, dicho título fue derogado por la Ley 25.248 de junio del año 2000.

Se debe destacar, centrándonos en la responsabilidad objetiva, que la Ley 24.441 estableció que:

"la responsabilidad objetiva del dador emergente del artículo 1113 del Código Civil se limita al valor de la cosa entregada en leasing cuyo riesgo o vicio fuere la causa del daño si el dador o el tomador no hubieran podido razonablemente asegurarlo y sin perjuicio de la responsabilidad del tomador". (Fundamentos del Anteproyecto del Código Civil y Comercial de la Nación, 2015)

Por su parte, la Ley 25.248 señalaba en su artículo 17 que "La responsabilidad objetiva emergente del artículo 1.113 del Código Civil recae exclusivamente sobre el tomador o guardián de las cosas dadas en leasing.

Con la modificación del tratamiento de la responsabilidad objetiva del dador del bien, la doctrina argentina se encontró dividida; sin embargo aquellos que defendieron lo propuesto en el artículo 17 antes citado, sostuvieron que dicho artículo tiene sentido porque no debe olvidarse que para una entidad financiera ser dueña de una cosa que da en leasing es un simple medio para financiar, y no un fin en sí mismo y que no 
debe perderse de vista que se trata de un negocio en que la titularidad dominial cumple una función de garantía, es el tomador quien debe responder, pues "el aprovechamiento económico del bien corresponde y beneficia exclusivamente él. (Negritas y subrayado es nuestro) (Weis, 2010, p. 826-827).

Cabe precisar que, mediante Decreto Presidencial 191/2011, se presentó el "Anteproyecto de Código Civil y Comercial de la Nación"; en dicho anteproyecto se establecía que:

El dador del leasing tiene la carga de contratar un seguro que cubra contra los riesgos ordinarios de responsabilidad civil que puedan causar los bienes objeto del contrato. Los riesgos y montos por los que debe contratar el seguro son los que establezca la reglamentación, o, en defecto de ésta, los que sean razonables. El damnificado tiene acción directa contra el asegurador, en los términos del contrato de seguro. $\underline{\text { El dador es }}$ responsable únicamente en los casos que no hava contratado este seguro. La responsabilidad del tomador se juzga según la responsabilidad por el hecho de las cosas. (Fundamentos del Anteproyecto del Código Civil y Comercial de la Nación, 2015) (Negritas y subrayado es nuestro).

De acuerdo a lo señalado en el Anteproyecto, dicha disposición buscaba "un equilibrio que contemple el derecho de las víctimas al resarcimiento y la necesidad de viabilizar este tipo de contratos".

A pesar de ello, y de la propuesta esgrimida en el caso de responsabilidad objetiva del dador, con fecha 07 de octubre de 2014, se promulgó el Código Civil y Comercial de la Nación, que recoge el contrato de leasing en el capítulo 5 del Título IV referido a “Contratos en particular". En dicho cuerpo normativo se mantuvo lo señalado en la Ley 25.248 referido a la responsabilidad objetiva. Así tenemos el artículo 1243 que a la letra dice:

Artículo 1243.- Responsabilidad objetiva. La responsabilidad objetiva emergente del artículo 1757 recae exclusivamente sobre el tomador o guardián de las cosas dadas en leasing.

Por su parte el artículo 1757 señala lo siguiente:

Artículo 1757.- Hecho de las cosas y actividades riesgosas. Toda persona responde por el daño causado por el riesgo o vicio de las cosas, o de las actividades que sean riesgosas o peligrosas por su naturaleza, por los medios empleados o por las circunstancias de su realización. La responsabilidad es objetiva. No son eximentes la autorización 
administrativa para el uso de la cosa o la realización de la actividad, ni el cumplimiento de las técnicas de prevención.

Como se puede apreciar, la legislación argentina si bien buscó un equilibrio con el anteproyecto propuesto, en la medida que obligaba al dador (arrendador financiero) a asegurar el bien entregado en Leasing de lo contrario asumía responsabilidad; mantuvo la disposición en que imputaba únicamente responsabilidad al tomador del bien (arrendatario), siendo específico al señalar que la responsabilidad objetiva recae en éste.

\section{- Colombia:}

El caso colombiano es muy interesante, pues si bien se emitió el Decreto № 913 de 1993 , norma en materia del ejercicio de la actividad de arrendamiento financiero o leasing, no se recogió en dicho dispositivo aspectos como la responsabilidad civil por daños ocasionados por el uso de los bienes otorgados en leasing. Será el Código Civil Colombiano utilizado como fundamento para vincular a las empresas de leasing como responsables por los daños y perjuicios que puedan causar los bienes entregados en arrendamiento financiero.

En efecto, el Código Civil en su título XXXIV, artículos 2341 a 2360 recoge lo correspondiente a la responsabilidad común por los delitos y las culpas; a partir del artículo 2356 y por vía jurisprudencial, se ha estructurado la responsabilidad derivada del ejercicio de las actividades peligrosas.

El artículo 2356 del Código Civil señala lo siguiente:

Responsabilidad por Malicia o negligencia. Por regla general todo daño que pueda imputarse a malicia o negligencia de otra persona debe ser reparado por ésta.

Son especialmente obligados a esta reparación:

El que dispara imprudentemente un arma de fuego.

El que remueve las losas de una acequia o cañería, o las descubre en calle o camino, sin las precauciones necesarias para que no caigan los que por allí transiten de día o de noche.

El que obligado a la construcción o reparación de un acueducto o fuente, que atraviesa un camino, lo tiene en estado de causar daño a los que transitan por el camino.

Al respecto, Villa (2016) señala que: 
La Jurisprudencia colombiana ha desarrollado la responsabilidad por actividades peligrosa a partir del artículo 2356 del Código Civil, en consecuencia debe entenderse conforme a la jurisprudencia de la Corte: "Todo aquel que cause un daño en el ejercicio de una actividad peligrosa, está obligado a indemnizar a la víctima a menos que establezca una causa extraña" (p. 60).

Sin embargo, la Corte Suprema de Justicia Colombiana en reiterados pronunciamientos se funda en la premisa de no responsablidad del arrendador financiero, amparados en la denominada "teoría de la guarda de la actividad". En el caso específico del leasing, con la celebración del contrato se le transfirió al locatario la guarda material del bien, lo que implica que es él quien ejerce dicha guarda, controla, elige y vigila el bien y a las personas que lo operan y mantienen.

Al respecto, la Corte Suprema colombiana se ha pronunciado de la siguiente manera (Sala de Casación Civil, 4 de abril de 2013, Ref. Exp. N 11001-31-03-008-200209414-01):

"El responsable por el hecho de las cosas inanimadas es su guardián, o sea quien tiene sobre ellas el poder de mando, dirección y control independientes. $\mathrm{Y}$ no es cierto que el carácter de propietario implique necesaria e ineludiblemente el de guardián, pero sí lo hace presumir como simple atributo de dominio, mientras no se pruebe lo contrario...O sea, la responsabilidad del dueño por el hecho de las cosas inanimadas proviene de la calidad de guardián de ellas presúmese tener. Y la presunción puede desvanecerla el propietario si demuestra que transfirió a otra persona la tenencia de la cosa en virtud de un título jurídico, como el de arrendamiento, el de comodato, etc., o que fue despojado inculpablemente de la misma, como el caso de haberle sido robada o hurtada". (Negritas y subrayado es nuestro).

Como podemos apreciar del caso colombiano, si bien no existe una regulación sobre la responsabilidad civil del arrendador financiero por accidentes vehiculares, consideramos que la jurisprudencia con mucha claridad ha valorado la naturaleza jurídica propia del contrato de arrendamiento financiero, a través del desarrollo de la teoría del guardían.

Incluso, mediante resolución de la Corte Suprema de Justicia, Sala de Casación Civil, de fecha 2 de diciembre de 2011 se observó que:

“(...) la sociedad de leasing demandada en el momento del accidente no incurriría en una actividad peligrosa, pues su objeto social no lo constituye el transporte y por el contrario él se dirige a entregar bienes, entre ellos vehículos en arrendamiento a terceros, conducta 
que de suyo y para las presentes lides indemnizatorias, no es peligrosa, enunciación que deja descubierto que no existe nexo de causalidad, para llamarla en responsabilidad"

Es cierto que la legislación colombiana no desarrolla la responsabilidad objetiva, tal como es recogida en nuestro país, pero es claro que los tribunales colombianos han ido más allá que nuestros tribunales, pues la sola condición de propietario del bien no basta para imputar responsabilidad al arrendador financiero frente a los accidentes vehiculares que se pueden producir.

\section{- Otras legislaciones:}

En el derecho comparado también debemos mencionar el caso uruguayo y de San Salvador. En el primer caso, el leasing es regulado mediante la Ley $\mathrm{N}^{\circ} 16.072$, que aprueba el contrato de uso que se refiere al contrato de crédito con los usuarios. En dicha Ley se define al leasing como:

"El contrato de crédito por el cual una institución financiera se obliga frente al usuario a permitirle la utilización de un bien por un plazo determinado y el usuario se obliga a pagar por esa utilización un precio en dinero abonable periódicamente. Podrá pactarse, en favor del usuario, una opción irrevocable de compra del bien, al vencimiento del plazo y mediante el plazo de un precio final" (Artículo 1).

Por su parte, el artículo 28 del citado dispositivo legal señala que:

"La obligación de reparar el daño causado a terceros por la cosa objeto del contrato, conforme al artículo 1324 del Código Civil; recaerá exclusivamente sobre el usuario, cuando el hecho dañoso haya ocurrido después de la recepción y antes de la devolución del bien por dicho usuario".

Cabe precisar que el artículo 1324 del Código Civil señala lo siguiente:

Hay obligación de reparar no sólo el daño que se causa por hecho propio, sino también el causado por el hecho de las personas que uno tiene bajo su dependencia o por las cosas de que uno se sirve o están a su cuidado. (...) La responsabilidad de que se trata en los casos de este artículo cesará cuando las personas en ellos mencionadas prueben que emplearon toda la diligencia de un buen padre de familia para prevenir el daño.

Como se aprecia de la legislación uruguaya, ésta se mantiene bajo la línea de no atribuir responsabilidad civil al arrendador financiero por su sola condición de propietario, 
incluso dicho país suele identificar al leasing como crédito de uso, en una clara alusión a su verdadera naturaleza jurídica el de ser un contrato de financiamiento.

En el caso de El Salvador, el arrendamiento financiero se encuentra recogido en el Decreto $\mathrm{N}^{\mathrm{o}} 884$ y específicamente en su artículo $6^{\circ}$ establece las obligaciones del arrendatario:

Art. 6.- El Arrendatario se obliga, durante la vigencia del contrato de arrendamiento financiero, a:

$(\ldots)$

b) Asumir los riesgos y beneficios asociados con la naturaleza puramente física y económica del bien;

c) Responder, civil y penalmente, por el uso del bien arrendado.

(...) (Negritas y subrayado es nuestro).

Como se aprecia de la legislación del El Salvador, el Arrendatario responderá obligatoriamente por los daños y perjuicios que directa o indirectamente, se ocasionen con o por el bien; de esta manera puede ser demandado civil o penalmente por el mal uso del bien.

Asimismo, lo interesante de la legislación salvadoreña, es que el Decreto $\mathrm{N}^{\mathrm{o}} 884$ en su artículo 21 recoge expresamente que la Ley de Arrendamiento Financiero, por su carácter especial, prevalecerá sobre cualquier otra que la contraríe. En ese sentido, dicho país tiene sumamente claro que el contrato de leasing, al ser un contrato moderno distinto a la contratación tradicional debe ser regulado en su forma, fines, características y obligaciones por una ley especial que recoja exclusivamente dicho contrato.

\subsection{Propuesta de solución del marco jurídico:}

Antes de plantear nuestra propuesta de solución, debemos preguntarnos: ¿Es el seguro, exigido por Ley, suficiente para solucionar el problema aquí planteado o se requiere una modificación a la normativa vigente sobre la responsabilidad civil del arrendador financiero por accidentes vehiculares?

La Ley de Leasing y su Reglamento establecen la obligación de la arrendataria de asegurar obligatoriamente el bien materia de arrendamiento financiero contra riesgos de responsabilidad civil frente a terceros. Incluso, el artículo 1987 del Código Civil establece 
que: "La acción indemnizatoria puede ser dirigida contra el asegurador por el daño, quien responderá solidariamente con el responsable directo de éste”.

Preliminarmente podemos señalar que, existiendo la obligación de asegurar los bienes por parte de la arrendataria, el arrendador financiero no tendría por qué verse perjudicado por la reiterada jurisprudencia que le atribuye responsabilidad al propietario de un bien considerado riesgoso o peligroso, o mediante el cual se ejerce una actividad riesgosa o peligrosa, aun cuando el mismo se hubiese entregado en leasing a un tercero.

Sin embargo, es práctica de las aseguradoras establecer condiciones para la aplicación de la cobertura de la póliza contratada y en caso no sean cumplidas por el asegurado, la empresa aseguradora quedará liberada de manera automática de las obligaciones emanadas de la póliza en cuestión.

Así por ejemplo tenemos las siguientes condiciones:

a) Responden hasta el límite de su póliza.

b) Que no se verifique la ocurrencia de las exclusiones previstas en la póliza; como por ejemplo el hecho doloso del asegurado, daños causados en estado de embriaguez o bajo el influjo de drogas, entre otros.

c) Dar aviso inmediato (dentro de las 24 horas) a la empresa aseguradora respecto a un evento que pueda dar lugar a responsabilidad civil del asegurado.

d) Abstenerse de celebrar negociaciones, acuerdos, reconocimiento de obligaciones o transacciones respecto de la responsabilidad materia del seguro.

e) A veces el siniestro no está cubierto porque los asegurados no están al día en los pagos de su póliza.

A mayor abundamiento, resulta pertinente citar las exclusiones contenidas en algunas pólizas de seguros. Tenemos por ejemplo, las Condiciones Generales de la póliza de seguro de autos de Mapfre Perú Compañía de Seguros y Reaseguros ${ }^{4}$, que señala en su artículo $5^{\circ}$ lo siguiente:

Artículo $5^{\circ}$.-Exclusiones

5.1 Exclusiones Generales

${ }^{4}$ https://www.mapfre.com.pe/images/condicionado-auto-0km tcm944-148922.pdf 
Cualquiera sea la cobertura contratada, salvo que en las Condiciones Particulares se consignara una cobertura o cláusula específica que estipule lo contrario; este seguro no cubre.

5.1.1 Los siniestros debidos a:

a) Deficiencias en el mantenimiento y/o en el uso del vehículo.

b) Desgaste y/o deterioro u otro motivo vinculado al uso del vehículo o por factores climáticos u otros de similar naturaleza.

c) Actos intencionales o negligentes del asegurado y/o del conductor del vehículo; así como los calificados como tales por la autoridad policial.

(..)

5.1.8 El siniestro que se produzca, mientras el vehículo hubiese estado:

a) Circulando en vías que no fuesen aptas para el tránsito del vehículo asegurado y/o fuera del radio de acción establecido por la póliza y/o circulando por vías o lugares no autorizados para el tránsito (...).

b) Tomando parte en carreras, competencias, apuestas o ensayos, pruebas de resistencia o de velocidad, prácticas de aventura o de carácter deportivo, u otro de uso arriesgado y/o distinto que dé lugar al aumento del riesgo ordinario.

c) Prestando servicio público en forma momentánea o permanente (...).

d) En poder de personas distintas del asegurado por haber sido capturado, embargado, confiscado o cedido con intervención de alguna autoridad o por haber sido apropiado o retenido en forma indebida.

e) Los daños ocasionados a terceros por haber sido robado o hurtado.

f) Siendo conducido por persona que carezca de licencia oficial para conducir y/o cuando la licencia de conducir se encuentre vencida, suspendida o cancelada y/o cuando teniendo licencia para conducir esta no faculta la conducción del vehículo siniestrado, según lo dispuesto por la legislación vigente.

g) Siendo por persona que está en estado de ebriedad o drogadicción. Se considera que existe ebriedad cuando el examen de alcohol en la sangre arroge un resultado superior a $0.50 \mathrm{gr} / 1 \mathrm{t}$, al momento del accidente (...) La Compañía quedará eximida de la obligación de indemnización cuando el conductor se niegue a practicarse, el 
examen de alcoholemia u otro que corresponda y sea requerido por la autoridad policial o por La Compañía.

h) Siendo conducido por persona que hubiere ingerido medicamentos cuyas indicaciones de laboratorio recomiendan abstenerse del manejo de vehículos.

i) Siendo conducido por persona que, en el momento del accidente, cometa una o más de las infracciones tipificadas como "Muy Graves" y/o "Graves" por el Reglamento Nacional de Tránsito o la norma legal vigente que lo sustituya.

j) Dentro de las zonas de aparcamiento, carreteo, despegue y aterrizaje de aeronaves, en aeropuertos y aeródromos, ya sean estos deportivos, civiles o militares.

k) Siendo conducido por personal que presta el servicio de estacionamiento.

1) Sometido a un servicio de reparación y/o mantenimiento.

\section{$(\ldots)$}

Por otro lado, en las Condiciones Generales de la póliza de seguros de Pácifico Seguros ${ }^{5}$, encontramos las siguientes exclusiones:

Artículo $6^{\circ}$

Riesgos no cubiertos y exclusiones

La Compañía no cubre lo siguiente:

$(\ldots)$

B. Siniestros debido a:

a) Desperfectos del sistema de "Airbag" o que hubiesen sido producidos a consecuencia de la activación accidental del "Airbag" o no producida por un accidente de tránsito.

b) Deficiencias en el mantenimiento y/o por el uso distinto al autorizado de la Unidad Asegurada y/o sobrecarga de la misma.

\footnotetext{
${ }^{5}$ http://site.pacificoseguros.com/terminos_pdf/AUTOMOVILES.pdf
} 
c) Las ocasionadas intencionalmente (dolo) por el propietario y/o conductor y/o asegurado y/o contratante de la unidad asegurada.

d) Negligencia del conductor, asegurado o contratante.

$(\ldots)$

E. Los siguientes casos:

$(\ldots)$

h) Cuando en la unidad asegurada, el número de ocupantes incluyendo el conductor supera el número de ocupantes indicado en la tarjeta de propiedad.

$(\ldots)$

H. Cuando el conductor:

a) Se encuentre en estado de embriaguez, ebriedad o drogadicción (...)

b) Circule en sentido contrario al tránsito autorizado o invadiendo el carril contrario.

c) Cruce una intersección o gire, estando el semáforo con luz roja y no existe indicación en contrario.

d) Desobedezca las indicaciones del efectivo de la Policía Nacional asignado al control de tránsito.

e) No respecta los límites máximos o mínimos de velocidad establecidos.

$(\ldots)$

Como se puede apreciar, si bien la norma establece también la responsabilidad solidaria de la empresa aseguradora, existen innumerables exclusiones recogidas en las pólizas de seguro, que genera que las aseguradoras no asuman los costos que se pueden generan por accidentes vehiculares. En consecuencia, resulta de suma importancia modificar el marco jurídico vigente en materia de responsabilidad civil por accidentes vehiculares, pues la responsabilidad solidaria del arrendador financiero siempre se mantendrá vigente en tanto no se logre una mayor precisión en la regulación actual.

Ahora bien, sustentados en la experiencia extranjera, proponemos establecer fórmulas legales claras y precisas que excluyan expresamente del ámbito de responsabilidad civil frente terceros al arrendador financiero, buscando que sea el 
Decreto Legislativo 299 y su Reglamento los que prevalezcan sobre lo dispuesto en la Ley General de Transporte y Tránsito Terrestre (Ley 27181).

Si bien es cierto que nuestro Código Civil, en el Título IV referido al contrato de arrendamiento, artículo $1677^{\circ}$ señala que: "El contrato de arrendamiento financiero se rige por su legislación especial y, supletoriamente, por el presente título y los artículos $1419^{\circ}$ a $1425^{\circ}$, en cuanto sean aplicables"; consideramos que ello no es suficiente para deslindar de responsabilidad civil al arrendador financiero frente a accidentes vehiculares, por lo que, en primer lugar, proponemos modificar y precisar el artículo 6 de la Ley de Leasing, en cuanto a su condición de norma especial, no debiendo aplicarse lo dispuesto en la Ley General de Tránsito y Transporte Terrestre y tampoco el Código Civil. En ese sentido, proponemos se adopte la fórmula legal siguiente:

Artículo 6 del Decreto Legislativo 299: Los bienes materia de arrendamiento financiero deberán ser cubiertos mediante pólizas contra riesgos susceptibles de afectarlos o destruirlos. Es derecho irrenunciable de la locadora fijar las condiciones mínimas de dicho seguro.

La arrendataria es responsable del daño que pueda causar el bien o el uso del mismo a terceros, desde el momento que lo recibe de la locadora. Esta disposición prevalecerá sobre lo dispuesto en la Ley $\mathbf{N}^{\circ}$ 27181- Ley General de Transporte y Tránsito Terrestre, el Código Civil y sobre cualquier otro dispositivo legal (El texto en negritas es el añadido).

Ahora bien, en el caso particular de los vehículos automotores, corresponde hacer la precisión en el artículo 29 de la Ley General de Transporte y Tránsito terrestre, proponiendo lo siguiente:

\section{Artículo 29.- De la responsabilidad Civil}

"La responsabilidad civil derivada de los accidentes de tránsito causados por vehículos automotores es objetiva, de conformidad con lo establecido en el Código Civil. El conductor, el propietario del vehículo y, de ser el caso, el prestador del servicio de transporte terrestre son solidariamente responsables por los daños y perjuicios causados.

\section{Dicha responsabilidad no aplica para el caso del arrendador financiero, siendo de} aplicación lo dispuesto en el Decreto Legislativo $\mathbf{N}^{\circ} 299$ y su Reglamento (el texto en negritas es el añadido).

A fin de evitar cualquier atisbo de responsabilidad civil frente a terceros del arrendador financiero, y siguiendo el mismo tenor de la modificación del artículo 29 antes citado, 
también resulta pertinente modificar lo dispuesto en el TUO del Reglamento Nacional de Responsabilidad Civil y Seguros Obligatorios por Accidentes de Tránsito, aprobado mediante Decreto Supremo N 024-2002-MTC, por lo que proponemos lo siguiente:

Artículo 2.- La responsabilidad civil derivada de los accidentes de tránsito causados por vehículos automotores se regula por lo dispuesto en el presente Reglamento y en el Código Civil. El conductor, el propietario del vehículo y, de ser el caso, el prestador del servicio de transporte terrestre son solidariamente responsables por los daños personales y materiales, así como perjuicios, causados a los ocupantes y terceros no ocupantes del vehículo automotor.

Dicha responsabilidad no aplica para el caso del arrendador financiero, siendo de aplicación lo dispuesto en el Decreto Legislativo $N^{\circ} 299$ y su Reglamento (el texto en negritas es el añadido).

Las propuestas de solución aquí planteadas se sustentan en las siguientes premisas:

a) El leasing como contrato de financiamiento constituye una herramienta fundamental para las personas pues otorga la posibilidad de adquirir bienes para su uso inmediato y directo, reduciendo los costos del crédito al mantener la titularidad de los bienes a favor del Banco o empresa de Leasing.

b) Parte de la Política de Estado es promover al Leasing como fuente de financiamiento a fin de dotar de bienes de capital a aquellas empresas que carecen de efectivo suficiente para adquirir tales bienes, implementando incluso una serie de beneficios tributarios que hace más atractiva esta figura.

c) La responsabilidad objetiva recogida en el artículo 1970 del Código Civil, se construye sobre la teoría del riesgo creado, teoría que busca atribuir responsabilidad a aquel que genera un riesgo directo e introduce el riesgo en la vida social. Asimismo, con dicho artículo se busca mitigar y prevenir la generación de daños por la utilización de bienes riesgosos o peligrosos.

d) En el caso de un contrato de arrendamiento financiero y basándonos en su naturaleza jurídica y también económica, podemos afirmar que el arrendador financiero no está en una situación de ventaja con relación al arrendatario para 
asumir los gastos producto de la generación de daños ni mucho menos está en una mejor posición para asegurar los bienes entregados en leasing, ya que a través de dicho contrato se busca financiar únicamente bienes de capital sirviendo de intermediario frente al requerimiento de adquisición de vehículos, maquinarias, entre otros, realizado por el propio arrendatario.

e) En la medida que nuestros tribunales sigan en la misma línea de interpretación con relación al Decreto Legislativo $\mathrm{N}^{\circ} 299$ y su Reglamento, aplicando en todos los casos la Ley General de Transporte y Tránsito Terrestre, es necesario aclarar el panorama a fin de no generar un desincentivo para los actores que participan en el contrato de arrendamiento financiero, más aun considerando que la póliza de seguro no es suficiente por las exclusiones que ésta puede contener.

f) Es menester señalar que, nuestro trabajo de investigación dista mucho de lo planteado en la tesis de Alida Araujo Moreno, en la medida que, de acuerdo a nuestra posición no basta ser "formalmente propietaria de un bien" para imputar responsabilidad al arrendador financiero, sino más bien hemos buscado analizar por qué nuestro sistema atribuye responsabilidad al propietario mismo, y tal situación no encaja en la figura del arrendamiento financiero ya que la empresa de leasing no está en mejores condiciones para reducir y/o controlar el riesgo por los daños que puede generar un bien riesgoso o peligroso, como si lo pudiera estar el propietario de un vehículo.

g) Por su parte, la tesis de Elizabeth Chaparro Quispe, si bien coincide con nuestra posición, en el sentido que no corresponde imputar responsabilidad al arrendador financiero por accidentes vehiculares, su enfoque va dirigido a analizar el por qué no debe generase más riesgos a los bancos ya que al hacerlo y obligarlo al pago de una indemnización, podría afectar el dinero de terceros que depositan la confianza en dichas entidades, generando un perjuicio no solo a los ahorristas sino al sistema económico. 
h) De la misma manera, si bien en la actualidad existen dos proyectos de ley que buscan modificar el Decreto Legislativo 299 y la Ley General de Tránsito y Transporte Terrestre (Proyecto de Ley 3777/2014-CR y 340/2016-CR), que actualmente se encuentran con Dictamen de la Comisión de Economía, Banca, Finanzas e Inteligencia Financiera y Transportes y Comunicaciones respectivamente, nuestra propuesta va dirigida a dotar de mayor claridad a las normas en cuestión a fin de que nuestros jueces y tribunales puedan aplicar correctamente el derecho.

i) El proyecto de Ley $N^{\circ} 3777 / 2014$ busca incorporar en el segundo párrafo del artículo 6 del Decreto Legislativo 299 lo siguiente:

\section{$(\ldots)$}

La arrendataria es responsable frente a terceros del daño que pueda causar el bien desde el momento que lo recibe de la locadora. Corresponde a la arrendataria asegurar obligatoriamente los bienes materia de arrendamiento financiero contra riesgos de responsabilidad objetiva frente a terceros.

De la misma manera, propone modificar el artículo 29 de la Ley 27181, Ley General de Transporte y Tránsito Terrestre de la siguiente manera:

$(\ldots)$

$\underline{\text { La responsabilidad civil por daños ocasionados con bienes que se encuentran }}$ sujetos a contratos de arrendamiento financiero suscritos por una empresa supervisada por la Superintendencia de Banca, Seguros y AFP, se rige por su ley especial.

k) Por su parte, el Proyecto de Ley 340/2016-CR, con el dictamen aprobatorio de la Comisión de Transportes y Comunicaciones, propone el siguiente texto sustitutorio del artículo 6 del Decreto Legislativo 299:

$(\ldots)$

La arrendataria es responsable del daño que puedan causar con el bien desde el momento que lo recibe de la locadora. Corresponde a la arrendataria asegurar 
obligatoriamente los bienes materia de arrendamiento financiero contra riesgo de responsabilidad objetiva frente a terceros.

Tratándose de contratos de arrendamiento financiero de vehículos automotores, el arrendatario del bien será responsable civil objetivo, así como también tercero civil responsable en procesos penales $y$ responsable administrativo por infracciones de tránsito y transporte cuando no se identifique al conductor.

De la misma manera y bajo el mismo texto que el proyecto de Ley $\mathrm{N}^{\circ}$ 3777/2014, propone modificar el artículo 29 de la Ley 27181, Ley General de Transporte y Tránsito Terrestre de la siguiente manera:

$\underline{\text { La responsabilidad civil por daños ocasionados con bienes que se encuentran }}$ sujetos a contratos de arrendamiento financiero suscritos por una empresa supervisada por la Superintendencia de Banca, Seguros y AFP, se rige por su ley especial.

1) Con las modificaciones propuestas en el presente trabajo de investigación, lograremos mayor predictibilidad en los pronunciamientos de los jueces y tribunales al tener leyes más claras y precisas en las cuales no quepa duda de la real naturaleza jurídica del leasing y mucho menos que, es el arrendatario y no el arrendador financiero, quien debe responder por todos los daños ocasionados a terceras personas por el uso de los bienes entregados en leasing.

\subsection{Conclusiones del capítulo:}

Con el desarrollo del presente capítulo hemos llegado a las siguientes conclusiones preliminares:

- La jurisprudencia en nuestro país ha sido unánime al atribuir responsabilidad al arrendador financiero frente a los accidentes vehiculares, señalando dentro de sus fundamentos que, el artículo 6 del Decreto Legislativo 299 no regula los supuestos de responsabilidad extracontractual ni limita o determina quién resulta responsable o quien debe resarcir un evento dañoso frente a terceros ajenos a tal acto. De la misma manera, se señala que ante accidentes ocasionados por vehículos automotores resulta de aplicación lo dispuesto en el artículo $29^{\circ}$ de la 
Ley General de Transporte y Tránsito Terrestre, que establece la responsabilidad solidaria entre el propietario, el conductor del vehículo, y el prestador del servicios de transporte terrestre, de ser el caso, aplicándose el principio de especialidad normativa.

- A nivel de juzgados civiles y Cortes Superiores de Justicia, hemos podido advertir pronunciamientos que realizan una interpretación finalista de las normas sobre responsabilidad civil, señalando claramente que, a tenor de lo dispuesto en el artículo 6 del Decreto Legislativo 299, pues dicho artículo regula la responsabilidad extracontractual frente a terceros y corresponde a la arrendataria responder exclusivamente por el daño ocasionado por el vehículo.

- El seguro no es suficiente para solucionar el problema planteado en el presente trabajo de investigación, resulta necesario una modificación al marco normativo vigente y ello se debe a que las aseguradoras establecen condiciones para la aplicación de la cobertura de la póliza contratada e incluso se establecen exclusiones de la misma y en la medida que el asegurado no cumpla o se encuentre inmerso en alguna de las exclusiones, la empresa seguradora quedará liberada de manera automática de las obligaciones emanadas de la referida póliza.

- En la legislación comparada hemos podido identificar casos en los cuales se exonera, expresamente, de responsabilidad al arrendador financiero, como es el caso de Argentina; pero en otros casos, no existiendo una norma específica que lo exonere de responsabilidad, la jurisprudencia ha sido la encargada de interpretar los dispositivos vigentes, señalando que el responsable por el hecho de las cosas inanimadas es su guardián, es decir quien tiene sobre ellas el poder de mando, dirección y control independientes, este es el típico caso de Colombia. 


\section{CONCLUSIONES}

- A lo largo del desarrollo del presente trabajo de investigación, ha quedado claro que el contrato de Leasing es un contrato de financiamiento, por el cual una de las partes del mismo (arrendatario) no cuenta con los recursos financieros suficientes para adquirir maquinaria, equipos o inmuebles previamente definidos por éste, por lo que acude a una entidad del sistema financiero para que financie la compra de los bienes requeridos por el arrendatario. En ese sentido, esta figura permite al arrendatario obtener del arrendador el uso y disfrute de un bien durante un periodo de tiempo establecido en el contrato a cambio de una renta o pago fraccionado, con opción a favor de la arrendataria de comprar dichos bienes por un valor pactado.

- Asimismo, del análisis de las diversas teorías que buscan dilucidar la real naturaleza jurídica del contrato de Leasing, hemos concluido que se trata de una figura sui géneris, que si bien tiene elementos del contrato de arrendamiento y compraventa, tiene características propias que lo diferencian como tal, siendo por tanto una figura unitaria con causa única, que no es otra que el financiamiento.

- Con relación a la responsabilidad civil extracontractual, se ha podido determinar que la misma se encuentra regulada en el artículo $1969^{\circ}$ del Código Civil, conforme al cual, todo daño producido por dolo o culpa resulta pasible de indemnización. Por otro lado, el artículo $1970^{\circ}$ del mismo cuerpo legal, recoge el criterio objetivo de responsabilidad sobre la base del riesgo creado, que se constituye como el factor objetivo de atribución de responsabilidad.

- En el caso de accidentes de tránsito, por el sólo hecho de encontrarnos frente al uso de un bien riesgoso (vehículos automotores), opera en forma automática el criterio de responsabilidad objetiva consagrado en el artículo 1970 del Código Civil frente al perjudicado, a fin de lograr el resarcimiento correspondiente de acuerdo al daño causado (Sentencia del Tribunal Constitucional, Expediente $N^{o}$ 0001-2005-PI-TC). 
- Nuestra jurisprudencia se ha centrado en señalar que, en el caso de responsabilidad civil del arrendador financiero, éste es responsable en aplicación de lo dispuesto en el artículo 29 de Ley General de Transporte y Tránsito Terrestre, que señala expresamente que el conductor, el propietario del vehículo y, de ser el caso, el prestador del servicio de transporte terrestre son solidariamente responsables por los daños y perjuicios causados. De la misma manera, en la diversa jurisprudencia analizada, se señala que lo dispuesto en la Ley de Leasing, referido a la responsabilidad civil, está destinada a regular el contrato mismo y los derechos y obligaciones que se dan entre las partes que lo celebran y no a regular los supuestos de responsabilidad extracontractual ni a limitar o determinar quién resulta responsable o quién debe resarcir un evento dañoso frente a terceros ajenos a tal acto.

- En virtud del principio general del derecho de especialidad normativa, la ley especial se aplicará con preferencia a la ley general pues su supuesto de hecho se ajusta más al hecho concreto; en ese sentido, es la Ley de Leasing la que mejor regula la figura contractual que hemos desarrollado a lo largo del presente trabajo; por tanto es dicha regulación la que debe primar sobre la Ley General de Transporte y Tránsito TerrestreLey $\mathrm{N}^{\circ} 27181$ e incluso sobre el Código Civil.

- Considerando las interpretaciones vertidas por nuestros tribunales con relación a la responsabilidad extracontractual del arrendador financiero por accidentes vehiculares es necesario modificar el marco normativo vigente, estando nuestro planteamiento avalado por la distinta legislación y experiencia extranjera a la que nos hemos referido en el presente trabajo de investigación. Con los aportes aquí planteados lograremos una legislación clara que evite encarecer esta importante fuente de financiamiento como es el leasing. 


\section{RECOMENDACIONES}

- A fin de fomentar el leasing como fuente de financiamiento en el Perú y tomando como ejemplo normativa extranjera, como el caso de Argentina, Colombia, Uruguay y El Salvador, es de suma importancia modificar toda aquella normativa que se pueda oponer o pueda dar lugar a interpretaciones equivocadas con relación a lo dispuesto en el artículo 6 del Decreto Legislativo 299, que regula el Contrato de Leasing, y su Reglamento.

- Resulta claro que el artículo 6 de la Ley de Leasing, precisa que el arrendador financiero no es responsable frente a terceros de los daños ocasionados por los bienes entregados en arrendamiento financiero y en todo caso será el arrendatario responsable ante una responsabilidad objetiva, estando a su cargo asegurar el bien ante ese tipo de responsabilidad. Sin embargo, es de suma importancia darle mayor claridad y precisión a fin de evitar las interpretaciones antojadizas de nuestros Tribunales. De la misma manera, resulta necesario modificar la Ley General de Transporte y Tránsito Terrestre y lo dispuesto en el TUO del Reglamento Nacional de Responsabilidad Civil y Seguros Obligatorios por Accidentes de Tránsito, aprobado mediante Decreto Supremo $\mathrm{N}^{\circ}$ 024-2002-MTC, que establece la responsabilidad solidaria de los propietarios de los vehículos automotores.

- Proponemos la modificación de los siguientes dispositivos legales, a fin de contar con normas claras y que no quepa duda en nuestros jueces y tribunales que es el arrendatario a quien se le debe imputar responsabilidad por accidentes vehiculares y no al arrendador financiero como lo vienen haciendo en la actualidad:

Artículo 6 del Decreto Legislativo 299: Los bienes materia de arrendamiento financiero deberán ser cubiertos mediante pólizas contra riesgos susceptibles de afectarlos o destruirlos. Es derecho irrenunciable de la locadora fijar las condiciones mínimas de dicho seguro. 
La arrendataria es responsable del daño que pueda causar el bien o el uso del $\underline{\text { mismo a terceros, }}$, desde el momento que lo recibe de la locadora. Esta disposición prevalecerá sobre lo dispuesto en la Ley $\mathbf{N}^{\circ}$ 27181- Ley General de Transporte y Tránsito Terrestre, el Código Civil y sobre cualquier otro dispositivo legal.

Artículo 29 de la Ley General de Transporte y Tránsito Terrestre.- De la responsabilidad Civil.-

La responsabilidad civil derivada de los accidentes de tránsito causados por vehículos automotores es objetiva, de conformidad con lo establecido en el Código Civil. El conductor, el propietario del vehículo y, de ser el caso, el prestador del servicio de transporte terrestre son solidariamente responsables por los daños y perjuicios causados.

Dicha responsabilidad no aplica para el caso del arrendador financiero, siendo de aplicación lo dispuesto en el Decreto Legislativo $N^{\circ} 299$ y su Reglamento.

Artículo 2 del TUO del Reglamento Nacional de Responsabilidad Civil y Seguros Obligatorios por Accidentes de Tránsito (Decreto Supremo N 024 2002-MTC).-

La responsabilidad civil derivada de los accidentes de tránsito causados por vehículos automotores se regula por lo dispuesto en el presente Reglamento y en el Código Civil. El conductor, el propietario del vehículo y, de ser el caso, el prestador del servicio de transporte terrestre son solidariamente responsables por los daños personales y materiales, así como perjuicios, causados a los ocupantes y terceros no ocupantes del vehículo automotor.

Dicha responsabilidad no aplica para el caso del arrendador financiero, siendo de aplicación lo dispuesto en el Decreto Legislativo $N^{\circ} 299$ y su Reglamento. 


\section{REFERENCIAS}

Alva Matteucci, M. (16 de Abril de 2012). El Contrato de Leasing y Depreciación Acelerada: ¿Se deprecia el terreno más edificación o solo la edificación? Obtenido de http://blog.pucp.edu.pe/blog/blogdemarioalva/2012/04/16/elcontrato-de-leasing-y-la-depreciacion-acelerada-se-deprecia-el-terreno-masedificacion-o-solo-la-edificacion/

Araujo, A. (2017). La Regulación de la Responsabilidad Solidaria del Arrendador Financiero en el contrato de Leasing (Tesis para optar el título profesional de abogado). Obtenido de Universidad Privada Antenor Orrego: http://repositorio.upao.edu.pe/bitstream/upaorep/2877/1/RE_DERE_ALIDA.AR AUJO_REGULACION.DE.LA.RESPONSABILIDAD_DATOS.pdf

Arias- Schreiber, M. (1999). Los Contratos Modernos. Lima-Perú: Gaceta Jurídica Editores.

ASBANC. (04 de Octubre de 2016). Asociación de Bancos del Perú. Obtenido de http://www.asbanc.com.pe/Informes\%20de\%20Prensa/ARRENDAMIENTO_FI NANCIERO_Julio_2016.pdf

ASBANC. (16 de Febrero de 2017). Asociación de Bancos del Perú. Obtenido de http://www.asbanc.com.pe/Informes\%20de\%20Prensa/ARRENDAMIENTO_FI NANCIERO_Diciembre_2016.pdf

Beltrán Pacheco, J. A. (Mayo 2015). Cuando el banco cree que lo puede todo. Resarcimiento vs. contrato de arrendamiento financiero. Diálogo con la Jurisprudencia(55).

Bravo, S. (2010). Contratos modernos empresariales: Contratos atípicos e innominados. Lima-Perú: Ediciones Legales.

Bullard, A. (2010). Derecho y Economía. El análisis económico de las instituciones legales. Lima: Palestra Editores.

Chaparro, E. (2017). Arrendamiento Financiero y la Responsabilidad Extracontractual de los Bancos (Tesis para optar el grado de Magister en Derecho Bancario y Financiero). Obtenido de Pontificia Universidad Católica del Perú: http://tesis.pucp.edu.pe/repositorio/bitstream/handle/123456789/8105/CHAPAR RO_QUISPE_ELIZABETH_ARRENDAMIENTO_FINANCIERO.pdf?sequen $\underline{\mathrm{ce}=1 \& \text { isAllowed }=\mathrm{y}}$

De Trazegnies, F. (2003). La Responsabilidad extracontractual (Vol. Tomo II). LimaPerú: Fondo Editorial de la Pontificia Universidad Católica del Perú.

De Trazegnies, F. (2015). Responsabilidad por Riesgo. En Tratado de Responsabilidad Civil Contractual y Extracontractual (págs. 71-86). Lima-Perú: Pacífico Editores S.A.C. 
De Trazegnies, F. (2016). La Responsabilidad Extracontractual. T.I. Lima: Ara Editores.

Díaz, J. L. (2009). El Contrato de Leasing. En Contratos Mercantiles (pág. 1286). España: Aranzadi S.A.

Effio Pereda, F. (s.f.). ¿Como contabilizar un arrendamiento financiero y un retroarrendamiento financiero? Obtenido de Asesoria Empresarial: http://www.asesorempresarial.com/libros/AFRAF_12/LV_ARREND_FINA_12. $\underline{\mathrm{pdf}}$

Espinoza, J. (2016). Derecho de la Responsabilidad Civil. Lima: Instituto Paífico S.A.C.

Falla, A. (1994). Accidentes, Responsabilidad Civil y Propósitos Sociales. Obtenido de http://www.bullardabogados.pe/publications/wpcontent/uploads/2011/12/1994af_accidentes.pdf

Fernández Cruz, G., \& León, L. (2005). Comentarios al artículo 1970 del Código Civil. En Código Civil comentado por los 100 mejores especilistas. Lima: Gaceta Jurídica.

Flores, M. d. (1998). El leasing internacional en el Tratado de Unidroit. Recuperado el 30 de Noviembre de 2015, de http://eprints.ucm.es/1533/1/PA_LHDuque.pdf

Fundamentos del Anteproyecto del Código Civil y Comercial de la Nación. (30 de Noviembre de 2015). Obtenido de http://www.nuevocodigocivil.com/wpcontent/uploads/2015/02/5-Fundamentos-del-Proyecto.pdf

Leyva, J. (Diciembre de 2003). El Leasing y su configuración jurídica. Recuperado el 15 de Octubre de 2015, de http://www.redalyc.org/articulo.ao?id=82510620

Lorenzetti, R. L. (2001). Derecho Contractual. Nuevas Formas Contractuales. LimaPerú: Palestra Editores.

Montoya Alberti, U., \& Montoya Alberti, H. (2004). Contrato de Leasing. En U. Montoya Alberti, Derecho Comercial (págs. 349-420). Lima: Editora Juridica Grijley.

Navarro, I. (2003). El Contrato de Leasing. En Tratado de Derecho Mercantil (Vol. III, págs. 547-582). Lima-Perú: Gaceta Juridica.

Peschiera Mifflin, D. (2008). El leasing o arrendamiento financiero y el financiamiento de proyectos: potencialidades aun sin explotar en el Perú. IUS ET VERITAS, 4662 .

Polar, N. (2000). Ventajas y Desventajas del Contrato de Arrendamiento Financiero. Obtenido de www.revistas.pucp.edu.pe/index.php/themis/article/view/11677/12227

Ramos, J. A. (2014). La fiscalidad del leasing en el Impuesto a la Renta y el Impuesto General a las Ventas. Caballero Bustamente.

Soto, C. A. (2015). Tratado de Responsabilidad Civil Contractual y Extracontractual. Lima: Instituto Pacífico. 
Tardío, J. (Setiembre-Diciembre de 2003). El principio de especialidad normativa (Lex Specialis) y sus aplicaciones jurisprudenciales. Recuperado el 17 de Noviembre de 2015 , de http://www.serranocid.com/documentos/Principio\%20de\%20Especialidad\%20N ormativa..pdf

Torres, A. (2011). Código Civil. Lima: IDEMSA.

Uribe, S. (2003). La Responsabilidad por Riesgo. Obtenido de www.juecesyfiscales.org/descargas/riesgo.zip?ml=S\&

Uriburú, J. H. (2009). Introducción al sistema de responsabilidad civil peruano. LimaPerú: Grijley.

Valenzuela, H. (2004). Responsabilidad Civil por Accidentes de Tránsito y Seguro Obligatorio. Lima: Ara Editores.

Vidal, F. (2013). La Responsabilidad Civil Extracontractual: El Sistema adoptado en el Código Civil de 1984. Recuperado el 7 de Noviembre de 2015, de http://revistas.pucp.edu.pe/index.php/derechopucp/article/viewFile/5951/5960

Villa, L. F. (2016). La Responsabilidad Civil Extracontractual y Solidaria de la Sociedad de Leasing en el escenario del Contrato de Leasing Automotor (Tesis para opar el título de abogado. Obtenido de http://biblioteca.udenar.edu.co:8085/atenea/biblioteca/91548.pdf

Weis, C. (2010). Contrato de Leasing. En E. Martorell, Tratado de Derecho Comercial (págs. 731-856). Buenos Aires: La Ley. 